\title{
The Explosion of Ethnic Retributive Violence in Czechoslovakia at the End of the Second World War
}

\author{
Bryson David Taylor \\ West Virginia University
}

Follow this and additional works at: https://researchrepository.wvu.edu/etd

\section{Recommended Citation}

Taylor, Bryson David, "The Explosion of Ethnic Retributive Violence in Czechoslovakia at the End of the Second World War" (2013). Graduate Theses, Dissertations, and Problem Reports. 418.

https://researchrepository.wvu.edu/etd/418

This Thesis is protected by copyright and/or related rights. It has been brought to you by the The Research Repository @ WVU with permission from the rights-holder(s). You are free to use this Thesis in any way that is permitted by the copyright and related rights legislation that applies to your use. For other uses you must obtain permission from the rights-holder(s) directly, unless additional rights are indicated by a Creative Commons license in the record and/ or on the work itself. This Thesis has been accepted for inclusion in WVU Graduate Theses, Dissertations, and Problem Reports collection by an authorized administrator of The Research Repository @ WVU. For more information, please contact researchrepository@mail.wvu.edu. 
The Explosion of Ethnic Retributive Violence in Czechoslovakia at the End of the Second World War

Bryson David Taylor

Thesis submitted to the Eberly College of Arts and Sciences at West Virginia University in partial fulfillment of the requirements for the degree of

\author{
Master of Arts \\ In \\ History
}
Robert Blobaum, Ph.D., Chair
Katherine Aaslestad, Ph.D. Joshua Arthurs, Ph.D.
Department of History

\begin{abstract}
Morgantown, West Virginia
2013
\end{abstract}

Keywords: Expulsion of Germans, Retributive Violence, Forced Deportations, Deportation of Germans, Sudeten Germans, Czechoslovakia 


\section{ABSTRACT \\ The Explosion of Ethnic Retributive Violence in Czechoslovakia at the End of the Second World War}

\section{Bryson David Taylor}

The end of the Second World War was not the end of the explosion of human rights abuses from the Nazi occupation of Eastern Europe. In Czechoslovakia as well as Poland, there were outbreaks of retributive violence driven toward the German ethnic minorities present within their liberated boundaries. In both cases, the governments of Poland and Czechoslovakia began a state sponsored, and Potsdam Conference approved program, of "orderly and humane" expulsions. While most twentieth and twenty first century historians have attributed these actions in Czechoslovakia as a continuation of the historical relationship between the Czechs and Germans of Bohemia and Moravia, this study's contention is that these actions fundamentally altered the relations between the two groups by eliminating the Germans. Czech-German relations had included not only competition and destructive actions, but also coexistence, cooperation and inter-marriage between the two groups.

This study utilizes primary and secondary source material to analyze the critical aspects of this relationship as it pertained to the Nazi occupation of the regions of Bohemia and Moravia and the postwar Czechoslovak administration of President Edvard Benes. Under the direction of Reichsprotektor Konstantin von Neurath and then Reichsprotektor Reinhard Heydrich, the Nazi Protectorate of Bohemia and Moravia was polarized along ethnic lines between those who were German, those who could be Germanized, and those who were undesirable. For the first time in Czech history, the traditional state of identity transience between Czech and German no longer existed. German atrocities, including the complete destruction of the village of Lidice as well as the arrest or destruction of all resistance groups pacified the Protectorate under the Nazis for the remainder of the war.

The suffering experienced under the Nazi occupation manifested itself as the Soviet Red Army liberated the region. The newly freed Czechs took the opportunity to take revenge upon the Germans, arresting many as collaborators, deporting the rest. This was a dynamic shift in the postwar relations between the two ethnic groups. Further intensifying this change were the directives issued by Czech President Edvard Benes in the Great Decree, which further penalized Germans based substantially on their ethnic heritage rather than their actions during the war. This study will further explore these policies as well as the effects of the international community. The final portion of this study will analyze the long-term effects that the expulsion of Germans from Czechoslovakia had on the state's future. It will especially look at the outbreak of debate centered on the repeal of the Benes decrees and the Czech accession to the European Union, which clearly demonstrates the importance of the topic of research even in the venue of modern minority policies in the European Union and modern relations between the Czech Republic and Germany. 


\title{
THE EXPLOSION OF ETHNIC RETRIBUTIVE VIOLENCE IN CZECHOSLOVAKIA
} AT THE END OF THE SECOND WORLD WAR

\author{
Bryson David Taylor
}

Thesis submitted to the Eberly College of Arts and Sciences at

West Virginia University in partial fulfillment of the requirements for the degree of

Master of Arts in History

Department of History

APPROVAL OF THE EXAMINING COMMITTEE

Katherine Aaslestad, Ph.D.

Joshua Arthurs, Ph.D. 


\section{Acknowledgements}

For all of the time and effort that went into the completion of this project, it quite simply could never have been completed without the help of others. First, I would like to thank my mentor and friend, Dr. James Daddysman for lending his support and expertise to encourage me in all of my endeavors. You are not only an excellent teacher, but also a true, Christian friend.

I would also like to thank my family for their patience, understanding, and help through every phase of this writing process. I know it was tough, but we made it!

To my fiancé, Andrea "Lizzy" Lough, thank you for sticking by my side, for proofing and editing, for putting up with me, and most of all for your love and support through this endeavor.

Finally, thanks to my committee for their help and encouragement in this endeavor. 


\title{
Dedication
}

\author{
In memory of Dorsey Dale Wilson \\ \& \\ In honor of Andrea Elizabeth Lough
}




\section{Table of Contents}

Introduction..................................................................................1

Historic Czech-German Relations ............................................ 7

Bohemia and Moravia under the Habsburgs ........................................ 7

World War I and the Birth of Czechoslovakia ...................................... 10

The First Czechoslovak Republic ................................................ 13

World War II and Czech German Relations................................ 16

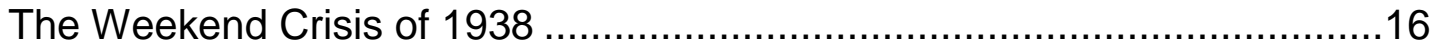

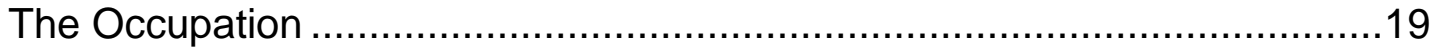

The Protectorate under Reinhard Heydrich ........................................... 25

Legalizing Deportations, Concentration and Confiscation ..........................29

Benes Abroad .............................................................................. 30

The Assassination of Heydrich and the Retaliation .................................

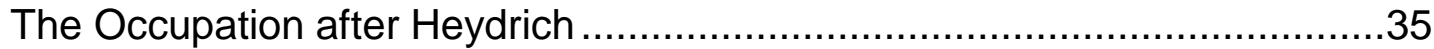

Planning the Expulsions .......................................................... 39

The End of the War .................................................................... 44

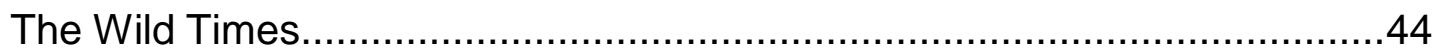

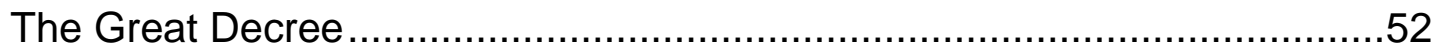

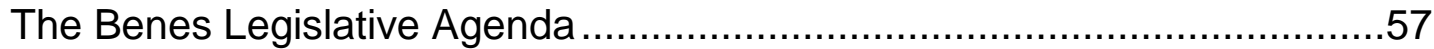

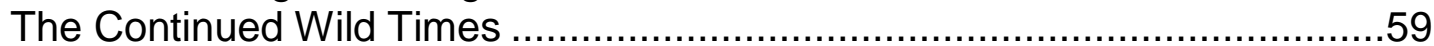

The Potsdam Agreement......................................................... 62

Conclusion ...............................................................................69 69

The Expulsions in Modern Memory .............................................69

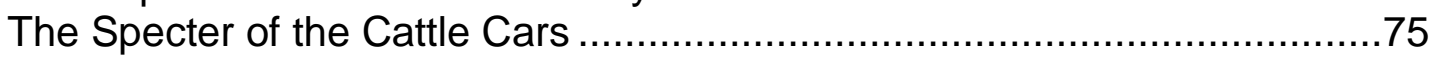

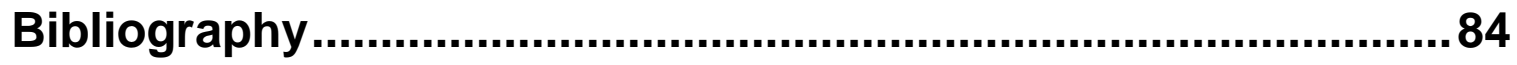




\section{The Explosion of Ethnic Retributive Violence in Czechoslovakia at the End of the Second World War}

The Second World War marked the greatest explosion of human rights abuses in history. The Nazi Third Reich sought the destruction of entire ethno-racial groups, the Jews and Roma (Gypsies) of Europe. However, to claim that the unconditional surrender of the German Wehrmacht ushered in a time of Pax Europa, or even a time of healing and rebuilding to follow the chaos, death, and destruction that devastated the European landscape for the previous six years, would be to omit one of the single largest periods of forced migration in human history. As the Soviet Red Army pushed back the Wehrmacht across the Eastern front, the newly liberated territories of the Soviet Union, Poland, Ukraine, Romania, Yugoslavia and Czechoslovakia all began the arduous process of forcibly expelling their German minorities, the often-misnamed Volksdeutsche, to the soon to be occupied territories of the former Third Reich. Ultimately, the actions of these states, with the vague sanction of the Potsdam Agreement, would permanently displace between twelve and fourteen million people. ${ }^{1}$

Most western historians have attributed the explosion of retributive violence and forced expulsions toward the minority German populations of Eastern Europe, as merely a sudden explosion of chaotic retaliation for the atrocities committed by the Nazi Third Reich, as well as for the actions of the prewar population of Volksdeutsche during the Nazi occupation. This approach to the narrative of the expulsions fails to consult the evidence effectively, choosing to overlook the actions of national leaders such as Edward Benes in their chosen course of action against their state's minority German

\footnotetext{
${ }^{1}$ It is important to note that the Potsdam agreement only approved the legal transfer of Volksdeutsche from the Soviet occupied territories, Poland, and Czechoslovakia, but other Eastern European nations forced their own German populations into Poland and Czechoslovakia to emigrate.
} 
population. The historical scholarship, which seeks to explain the expulsion of Germans from Eastern Europe as merely a (Nazi) German action, Eastern European reaction, also fails to address many of the questions that have arisen in the six decades after the expulsions. Why did the expulsions occur following the Second World War, rather than during the haphazard drawing and redrawing of state boundaries at the end of the First World War? Why, in a place considered to possess the most traditionally liberal government established in the wake of the Great War, did its leaders chose to remove the "problematic" segments of their German population through the clearly anti-liberal program of "wild" and "organized" expulsions? Why did the Allied powers, the United States, Soviet Union, Great Britain, and even France permit the expulsions by means that resembled those of German-inspired forced immigration and resettlement?

The historiographical scholarship that surrounds the expulsion of Germans from Czechoslovakia, as well as the rest of Eastern Europe, has expanded drastically over the last twenty years. Alfred de Zayas in his works, A Terrible Revenge: The Ethnic Cleansing of the East European Germans, 1944-1950 (1993), and Nemesis at Potsdam: The Anglo-Americans and the Expulsion of the Germans: Background, Execution, Consequences (1977), both provide a breakthrough in the use of primary sources and first hand-accounts into Western research of the expulsions throughout Eastern Europe. However, de Zayas's analysis of the sources collected tends to generalize expellee's experiences throughout the East, with only nominal differentiation between Polish, Czech, Soviet, and Yugoslav experiences. Benjamin Frommer's National Cleansing: Retribution against Nazi Collaborators in Postwar Czechoslovakia provides a significant overview of the process of retribution within Czechoslovakia, but it 
does not address the psychological impact of the Nazi occupation and looks at the motivations behind the expulsions as solely an element in the continued reciprocal relationship of Czechs and Germans. Historian Andrea Orzoff's study, Battle for the Castle: The Myth of Czechoslovakia in Europe 1914-1948, provides incredible insight into how the Czech leadership in its pursuit of a living national myth, assisted in the orchestration of ever-increasing tension between the Germans and Czechs. However, where her work exclusively analyzes the events of the expulsions through the prism of nationalist mythology, this study will seek to address the analogous relationship between Czech ethnic expulsions and German racial destruction.

Chad Bryant's Prague in Black: Nazi Rule and Czech Nationalism is arguably one of the best studies of the psychological impact that the Nazi occupation of Bohemia and Moravia had on the Czech population. Bryant's work operates within the paradigm of a reciprocal relationship between Czechs and Germans. This reciprocal relationship provides a valid paradigm for the preponderance of historic Czech-German Relations, but it fails to acknowledge one simple fact—-the Germans occupied and planned to Germanize the bulk of the Czech population, but the Czech leadership actively sought and for the most part executed the complete removal of its German problem through expulsion. Rather than following the dictum of action-reaction, the Czech authorities acted to settle the question of Czech versus German permanently. Bryant's work will play an integral role in this thesis. Also, the latest publication that addresses the forced deportations of Germans from Eastern Europe, R.M. Douglas's Orderly and Humane: The Expulsion of the Germans after the Second World War will play a significant role in the basis of this study. Douglas's work provides a well-rounded account of the 
expulsions in relationship to all of the Eastern European nations from prewar through the fall of communism. ${ }^{2}$

This thesis contends that the existing relational tension between Czechs and Germans was superseded by the psychological impact of Nazi rule. The outside force of Nazi rule induced Czech action toward Germans using methods similar to the Nazis without approaching the catastrophic ends that Hitler's Final Solution envisioned. The Czechs took the initiative to act in the interest of peace and stability in non-ethnic terms through the expulsion of the German population with whom they had shared these lands for centuries, regardless of their collaboration with or resistance to the Nazis. Not even those Czechs whom were considered for Germanization were safe from the deportations once they were racially identified as "German." The Czechs acted unilaterally, legally and literally changing the ethnic demographics of their nation, in order to ensure that the events of the Second World War never repeated. The influence of outside forces and pressures, coupled with the opportunity to end the competitive relationship between the two groups, induced one of the largest transfers of population in the twentieth century.

There is an uncanny correlation between the legal approach of the Nazi regime, and the postwar national councils of Czechoslovakia. From evidence gathered from several sources, one may very well gather that the Nazi plans for the racial cleansing of the Protectorate provided the blueprint for the methods of the subsequent concentration and deportation of the Germans. This paper will explore within the relevant research and resources for evidence of the psychological nature of the Nazi occupation, which

\footnotetext{
${ }^{2}$ For the complete bibliographical references, see the bibliography located at the end of this paper.
} 
led to Czech proactive measures against native Bohemian and Moravian

Volksdeutsche. Among these sources, it is important to note that there are some that date back to the 1950 s, which means that they carry with them significant political baggage, derived from their partisan Czech, German, and Cold War origins. Their use in most western scholarship does not add to their validity; thus, historians must examine these sources with a careful, critical eye. For this thesis, the documents reproduced within these sources are utilized without reference to the accompanying text provided by the editor or author. ${ }^{3}$

It is also important to note, that in no way does this study seek to equate the deeds of the Czech government in the expulsion of their country's German minorities with the barbarous and atrocious nature of the Nazi pursuit of the destruction of Jews, Roma, and others during the Holocaust. Although there are considerable correlations in the manner in which both groups sought to deprive their victims of their own human status, to equate them on a scale of heinousness and barbarity would serve very little than to dilute the tragic legacy of the Holocaust, an endeavor that only revisionist historians would view as useful. This study only seeks to demonstrate the relationship between the postwar expulsion policies and the means by which the Nazis deported Jews and others to concentration and extermination camps. Both Germans and Czechs

\footnotetext{
${ }^{3}$ These controversial sources include: Jivi Dolezal and Jan Kren, eds., Czechoslovakia's Fight: Documents on the Resistance Movement of the Czechoslovak People, 1938-1945, (Prague: Czechoslovak Academy of Sciences, 1964); and Lesson from History: Documents concerning Nazi Policies for Germanization and Extermination in Czechoslovakia, (Prague: Orbis, 1960) ; and Theodor Schieder ed. Documents on the Expulsion of the German Population from Czechoslovakia. Vol. 4, (Bonn: Federal Ministry for Expellees, Refugees, and War Victims, 1960).
} 
did this, but only the Germans chose the genocidal approach of the Final Solution, rather than only seeking deportation.

The organization of this paper will serve to highlight the special case of the expulsions in the regions of Bohemia and Moravia in Czechoslovakia. ${ }^{4}$ The paper will begin with a brief exploration of the historical relationship between Czechs and Germans in Bohemia and Moravia during the era of the Austro-Hungarian Empire and after the First World War. The paper will then begin to explore the actions and effects of Nazi administration of the Protectorate of Bohemia and Moravia during the Second World War. The policies of Czechoslovak president Edvard Benes and communist leader Klement Gottwald, as well as other prominent Czech leaders during the Second World War in the Protectorate and abroad, will be featured as evidence of the psychological impact on the Czech national consciousness created by the German occupation of Bohemia and Moravia. This paper will then proceed to analyze critically the documentary records of both the Reichsprotektor's administration and the Czech National Committees that emerged at the end of the Second World War. It is in this part of the analysis that the clear connection between the wartime occupation and the post war deportations truly takes shape and proves to the reader that the Nazi policies pursued within the protectorate of Bohemia and Moravia served as part of the inspiration and psychological breakthrough necessary for the perpetration of the expulsion of minority Germans from Czechoslovakia. Ultimately, the Czechs went beyond the rules of coexistence and sought to end, once and for all, their relationship with the Germans.

\footnotetext{
${ }^{4}$ For a broader historical survey of the expulsions' effects throughout Eastern Europe, please refer to the works authored by Alfred de Zayas and Benjamin Frommer cited within this study.
} 


\section{Historic Czech-German Relations}

\section{Bohemia and Moravia under the Habsburgs}

In order to comprehend fully what happened between Czechs and Germans during and after the Second World War, the historical relationship between these two ethnic groups within the regions of Bohemia and Moravia, as well as other regions that eventually became Czechoslovakia, must be understood. The historic tensions between these two groups began during the Thirty years war. Though this war began as a contest for supremacy between Catholics or Protestants, it would later serve as a hallmark of nationalist mythology. Thus, the story of the Battle of White Mountain transforms from a battle fought between a Catholic Habsburg Army and the protestant Hussites into a battle between German Catholics and Czech Protestants. This is too simplistic an explanation for the battle as Germans and Czechs fought on both sides of the battle. However, the loss of the battle ultimately led to the subjugation of Bohemia and Moravia, and its rebellious Czech element, as territory of the Habsburg Empire for the next three centuries. In an effort to consolidate its control over its rebellious territories, the Habsburgs deliberately moved significant numbers of German and other non-Czech nobles into the region in order to maintain the Habsburg dominion. This enraged local Czech nobles and established the contentious relationship between Czechs and Germans in Bohemia and Moravia. ${ }^{5}$

In order to maintain the loyalty of the Czechs to their Habsburg rulers, the Austrian administration of the region permitted the Czechs to have significant freedoms while trying to centralize its power in the region politically and culturally through legal

\footnotetext{
${ }^{5}$ Zdnek Fierlinger, "We Are Rectifying White Mountain," (Prague: Jednotny svaz cskych zemedelco, 1945) 3-4.
} 
means. The Czech language was permitted; however, all official government correspondence was required to be in German. Government sponsored high schools throughout Bohemia and Moravia taught their students only in the German language. In response to these "opportunities" provided by the government, Czechs opened private schools, which offered instruction in Czech. Equally important to the liberal Germans in the Habsburg government was the relationship between language and religion. The ebb and flow of the relationship of German action followed by Czech response continued to dictate the ethnic relations within Bohemian and Moravia. As the Austrian authorities made more and more attempts to centralize their control the region, the Czechs responded with their own efforts to maintain their Czech identity and national consciousness. Thus, succeeding generations of Czechs and Germans experienced transience in their identities. Within local Czech-dominated communities, in order to avoid discrimination, Germans needed to masquerade as Czechs through their own bilingualism. For individuals in official capacities, Czechs needed to demonstrate proficiency in German and be able to pass themselves off as pious "German Catholics." Further muddying the waters of ethnic identity were numerous intermarriages between Czechs and Germans that created greater biological and cultural links between the two groups. This transience of identity between "Germaness" and "Czechness" provided a level of equality amongst Germans and Czechs within the region, and for the most part, the two societies intermingled easily. ${ }^{6}$

The principal author of the Czech nationalist narrative that sought to transform relations between Czechs and Germans, Frantisek Palacky, argued that the region of

${ }^{6}$ Jeremy King, Budweisers into Czechs and Germans: A Local History of Bohemian Politics, 1848-1948, (Princeton, NJ: Princeton University Press, 2002) 16-20. 
Bohemia and Moravia that was under Slavic, Czech control during the Middle Ages was a cradle of democracy. According to Palacky, the Czechs were a "progressive hard working people" who created a variant of Slavic democracy that was unmatched in the world in the twelfth and thirteenth centuries. However, in the fourteenth century, the arrival of German immigrants undermined the traditional values of democracy and ultimately ended the splendor of Czech civilization. Palacky was the architect of the theoretical nationalist struggle embroiled in the religious alignment of the Battle of White Mountain. In other words, for the Czech nationalist narrative, the battle was not a struggle of Protestant against Catholic, or for the expansion of the Habsburg Empire, but rather it was a struggle between Germans and Czechs for national dominance in Bohemia. The repurposing of historical events such as the Battle of White Mountain is in no way without precedent in the construction of national narratives in the formation of nation-states. However, in the case of Czechoslovakia, by the late nineteenth century, the creative transformation of the Battle of White Mountain from a religious struggle into a national-political struggle for supremacy became a hallmark of Czech nationalists in their struggles with their German counterparts. ${ }^{7}$

In the nineteenth century, the region's Czech and German nationalists grew increasingly frustrated with the ease by which individuals could be German or Czech based entirely upon which group's membership was most advantageous at the time. Czech nationalists took every opportunity to limit the transience of identity, or force Czechs to embrace their Czech heritage. For most Czech nationals, however, the seemingly magnanimous steps of the Habsburg Empire to provide some autonomy to

\footnotetext{
${ }^{7}$ Andrea Orzoff, Battle for the Castle: The Myth of Czechoslovakia in Europe 1914-1948, (New York: Oxford University Press, 2011) 36-38.
} 
its ethnic enclaves kept them loyal to the empire. Even when the Habsburg Emperor Franz Josef established the dual-monarchy of Austria-Hungary in order to squelch cries for independence from the Magyars, few Czechs expressed outrage that their own national group was not given the same opportunity. It was not until the outbreak of the First World War that the Czech nationalist narratives began to gain traction in Czech consciousness and ushered in a change in the paradigm of Czech-German Relations in Bohemia and Moravia. $^{8}$

\section{World War I and the Birth of Czechoslovakia}

The Austro-Hungarian Empire took several pragmatic actions in an effort to stave off its demise throughout the latter half of the nineteenth century and in the beginning of the twentieth. The empire was an aging holdover from the Middle Ages that required massive transformation and reinventions to survive in the modern area. By the early 1900s, the Austrian Emperor Franz Josef faced significant nationalist movements that challenged the existing order. His heir apparent, the Archduke Franz Ferdinand, attempted to alleviate the internal pressures of nationalist sentiment by promising to decentralize much of the empire's decision-making, which in turn would have granted greater autonomy to the Empire's eleven national groups. With the prospective succession from Franz Josef to Franz Ferdinand, it seemed that the empire would once again reinvent itself and survive in the age of nation-states. However, the ethnic tensions, which plagued the Habsburg Empire since the nineteenth century, reached

\footnotetext{
${ }^{8}$ King, 36-38.
} 
critical mass in 1914 when the assassination of the Archduke Franz Ferdinand by Serbian nationalists plunged the entire European Continent into war. ${ }^{9}$

The outbreak of the First World War presented Czech nationalists with an opportunity to begin agitating for an independent Czech state. During the initial phases of the war, many of Bohemia's Czechs, as well as Germans, served in the AustroHungarian Army, demonstrating their continued support for the ruling dynasty, Emperor Franz Josef. However, as the war dragged on, it consumed more treasure, blood, and lives. Czech nationalists seized upon the flailing war effort and disgruntled public opinion, to begin pushing for independence. When this effort appeared to fail, and the victory for the Allies seemed far more certain, Czech nationalists including Tomas Masaryk and Edvard Benes traveled to London and Paris to begin lobbying the Allied leadership of Britain, France, the United States, and Italy for the establishment of an independent Czech state. The nationalist movement continued to gain momentum on the ground in Bohemia and Moravia through the clever use of propaganda to create a unified Czech nationalist narrative. ${ }^{10}$

Palacky's nationalist interpretation of Czech history was greatly embraced and heavily utilized by Masaryk, the future Czechoslovak president, as he lobbied people in the homeland to rally around the creation of a new, entirely Czech=led nation. Further assisting Masaryk's rhetoric of independence was the entry of the United States into the war against Germany and the Austro-Hungarian Empire. The American President, Woodrow Wilson, proposed fourteen points that provided the foundation for the postwar peace. In this outline, one of the key foundations of peace in the future depended upon

${ }^{9}$ G.J. Meyer, A World Undone: The Story of the Great War 1914 to 1918, (New York: Bantam Dell, 2006) 7-14.

${ }^{10}$ Orzoff, 28-29. 
the international acceptance of national self-determination in regions throughout Europe including Bohemia and Moravia. To Woodrow Wilson, every nationality had the right to choose for itself, its future administration. Under the direction of Masaryk and his future foreign minister, Edvard Benes, a group of Czech nationalists lobbied London, Paris, and Washington in an effort to assure the creation of a separate Czech state. Following the logic of power politics, Masaryk also ordered newly formed Czech military units to the borders of the desired Czech nationalist state, theorizing that it would be a near impossibility for the Allies to take away territory already occupied by Czech forces. The British embraced the idea and quickly brought the reluctant Americans around. With the support of two of the Big Four, the peace negotiation at Versailles announced the creation of a state that housed two of the Slavic national groups in Eastern Europe, the Czechs and the Slovaks, into the newly established state of Czechoslovakia. This created a large state that helped buffer the rest of Europe from the Soviet Union. ${ }^{11}$

Masaryk was a fervent patriot of the Czechoslovak cause. He believed that the Czechoslovak Republic had the historic aptitude and the current potential to become a shining beacon of Democracy in Eastern Europe. Benes, his lieutenant, on the other hand, has been described by historian R. M. Douglas as a true Machiavelli of the twentieth century, latching onto and pursuing any cause that ultimately resulted in the elevation of his own prestige and power. Together, Masaryk and Benes labored exhaustively in the interest of Czech nationalists and ultimately created the First Czechoslovak Republic. ${ }^{12}$

\footnotetext{
${ }^{11}$ David A. Andelman, A Shattered Peace: Versailles 1919 and the Price We Pay Today. (New Jersey: John Wiley \& Sons Inc., 2008) 140-143.

${ }^{12}$ R.M. Douglas, Orderly and Humane: The Expulsion of the Germans after the Second World War, (New Haven: Yale University Press, 2012) 12-13.
} 
During the First World War, the paradigm of German (Habsburg and native German nationalist) action, Czech reaction, continued to dictate the relationship between Bohemia and Moravia's Czechs and Germans. By the end of 1919, the Czechs came back to power after three centuries and ushered in a new shift in that paradigm, where no longer were the Germans' the power in regional politics, but the Czechs seized the initiative in the relationship. However, having power, keeping power, and continuing the Czech nationalist myth of republicanism proved to be the crux of the problems, which faced the newly developed Czechoslovak state in the coming decades. The First Czechoslovak Republic

The first major task before Masaryk and Benes was to secure the borders of Czechoslovakia. The borders between Austria, Czechoslovakia, Poland, and Germany remained unsettled. Reports, both factual and fabricated, poured into the new Czechoslovak government of border skirmishes between German and Czech military and paramilitary units on the frontier. Masaryk ordered the Czech military to the German border to provide greater security for Czech civilians against the German cross border raids. However, the events still damaged Czech-German relations on the ground as Czech mobs rounded up and killed several Bohemian Germans as participants in, or at the minimum sympathizers, with the armed German guerilla units. Only later did government officials finally admit that the suggested number of violent incidents was significantly inflated. Within the government, the first calls for the removal, sequestration, or at the minimum limited government participation of the German minority began. Masaryk attempted to satiate the demands of his lieutenants, including Benes, by signing into law policies that excluded many Germans from civil 
service jobs and official government positions. These laws kept most Germans from serving in the state administration, but it did provide Germans with the opportunity to participate in local governments, especially those local administrations in the Sudetenland. ${ }^{13}$

The strained relationship between Germans and Czechs continued to fray, despite Masaryk's attempts to satiate both sides to save the "golden age" of Czechoslovak republicanism and democracy. For the most part, the artificial legal separation of the two groups served to limit the functionality of the traditional transience of identity. Despite the attempts of the Czechoslovak government, in German communities, Czechs continued to act as Germans and in Czech communities, Germans acted as Czechs. Even with increased government pressure there was significant difficulty in defining Czech, German, or some combination thereof. The rise of right-wing extremist political parties (Fascist and Nazi parties) in Austria, Germany, and Italy increased nationalist paranoia within Masaryk's democratic party, and even he became alarmed. The rise of these parties, particularly the right-wing German led parties of Austria and Germany led Masaryk to approve further measures to minimize German influence in the state. Even more alarming to Masaryk was the fact that Hitler's Nazi Party in Germany was supporting the Sudeten Deutsch Partei (SdP) in local elections in the Sudetenland with monetary and political support. Benes was justifiably concerned with SdP activities. As seen in the SdP's Action Program of 1938, the SdP made the total destruction of Czech culture its ultimate goal:

The long-range aim must be: to smash up Czech national consciousness, penetration into hitherto Czech linguistic territory by German settlement, drawing

${ }^{13}$ Orzoff, 51-53. 
(partly through re-settlement) the Czech part of the nation into an indissoluble mental and physical connection with Germany.

The German national measures against the Czechs will require on our part supreme skill and energy in the application of the fighting and organizational principles of the German nation. The experience of our own German national struggle will have to prove itself. The application of the necessary measures will start, on the one hand, with the days and hours of military combat measures, and on the other hand, must be laid down systematically for generations to come. ${ }^{14}$

14 "Sudeten German Party's Action Programme of 1938," Lesson from History, 24. 


\section{World War II and Czech-German Relations}

The Weekend Crisis of 1938

By 1938, the upper hand in the relationship between Czechs and Germans in Bohemia and Moravia once again began to turn in favor of the Germans. In February of 1938, Adolf Hitler began a massive campaign within the German press, declaring natural solidarity between Reich Germans and those ethnic Germans residing in territories beyond the Reich's current boundaries. Specifically, Hitler referred to the millions of Volksdeutsche living under an oppressive government in Czechoslovakia. Hitler further argued that it was in the best interest for all Germans throughout Europe that the Reich expanded to include German nationals in the East. This incorporation of territories inhabited by Germans would free ethnic Germans from oppression under their current regimes and unite them with the Greater Third Reich. In Mein Kampf, Adolf Hitler described his desire for the Sudetenland to become a part of the greater Reich. For Edvard Benes, the President of Czechoslovakia, his justifiable concern over the loyalty of Sudeten Germans soon bordered on paranoia. He authorized the order to call up reservists and all military personnel to begin training for the defense of the Czechoslovak State. ${ }^{15}$

The paranoia that began with Hitler's rhetoric that declared the necessity for an expanded Reich only intensified when in March of 1938 Germany launched its Anschluss, the invasion and annexation, of Austria. Benes immediately ordered Czech troops to the German frontier. Further complicating the situation in April were the annual elections in the Sudetenland, scheduled for May 22, 1938. The SdP, with

\footnotetext{
${ }^{15}$ Guy Sutton, "The Weekend Crisis" of May 1938: Analyzing an Unsolved Mystery in Czechoslovakia-Nazi Germany Relations, (New York: I Universe, Inc, 2005) 2-3.
} 
immense help from the Third Reich's Bureau of Propaganda, owned a strategic stranglehold over the population in the region and expected enormous returns in the next election. A powerful political outcome would give the Sudeten Germans the chance to call for independence from Czechoslovakia and annexation into the Third Reich. This would prove to be a painful blow to the Benes' administration. Conceding dominance in the Sudetenland to Nazi Germany would subordinate the Czechoslovak state to German wishes and end the Benes administration's dominance in Czechoslovak politics. ${ }^{16}$

By the weekend of May 20-21, 1938, it became clear that the crisis brewing in the Sudetenland provided Hitler with an opportunity to undermine the postwar international system, as well as the nation of Czechoslovakia in the interest of the Sudeten Germans. Benes recognized this as a very real possibility and a very real threat to the independent Czechoslovak state. His order to mobilize the Czechoslovak military and strengthen its forces in the Sudetenland appeared a show of strength toward Germany that was meant to "intimidate" the Germans into refraining from any actions along the German-Czechoslovak frontier. In all actuality, it left Hitler with the opportunity to further "digest" the acquisitions made by the Reich in Austria before moving on to the Sudetenland, and ultimately the rest of the Czechoslovak state. ${ }^{17}$

By September of 1938, the confluence of events left Hitler feeling very comfortable with the planned annexation of the Sudetenland. Germans in the area were crying out for help, and his newfound alliance with Benito Mussolini's Fascist Italy coupled with the continued international support for appeasement gave him a free hand

\footnotetext{
${ }^{16}$ Chad Bryant, Prague in Black: Nazi Rule and Czech Nationalism, (Cambridge, Harvard University Press, 2007), 24-26.

${ }^{17}$ Sutton, 4-6.
} 
to operate in central Europe. In the Munich "Diktat" of 1938, Adolf Hitler, with the consent of the British and French, took control of the Sudetenland. Benes was certain that the British and French would never permit the unfettered expansion of the German Third Reich, and was taken totally by surprise with the announcement of the accord reached at Munich. He ultimately resigned and fled abroad. While this agreement only permitted the annexation of the Sudetenland, it became clear quickly that Hitler had designs for the remainder of Czechoslovakia. By March of 1939, with the movement of German troops into the remainder of the Czechoslovak state, its existence came to an end. ${ }^{18}$

On March 13, 1939, Adolf Hitler summoned the new Czechoslovak President Emile Hacha to Berlin. In the early hours of March 15, 1939, Adolf Hitler himself presented Hacha with an ultimatum: surrender all of Czechoslovakia to the Reich or the Wehrmacht would launch an invasion at six o'clock that morning. Hacha was given a direct line to Prague on which he ordered the Czechoslovak military to stand down. Any sign of resistance from the Czechoslovak military forces would result in the launch of a horrific attack on the people of Czechoslovakia. Herman Goering even threatened the immediate bombing of civilian targets to demonstrate to the rest of the world the power of the German Luftwaffe. At 4:30 that morning, Hacha gave a radio broadcast to the entirety of Czechoslovakia pleading with the population to remain calm and peaceful. The western regions of Czechoslovakia were incorporated into the Protectorate of Bohemia and Moravia. Slovakia was granted independent Axis ally status, and

${ }^{18}$ Orzoff, $175-177$. 
Hungary and Poland were subsequently awarded their own slices of Czechoslovak territory, which contained small minority Magyar and Polish populations. ${ }^{19}$

As a foreshadowing for his future labors on behalf of an independent Czechoslovakia, Edvard Benes, having fled abroad, espoused the Czech national narrative. The Czechs were the victims of Nazi aggression that ended the peaceful, equitable nature of the Czechoslovak State. This national myth would be a cornerstone in Benes' plans for retribution against the Sudeten Germans of Czechoslovakia by making the Czechoslovak state the victim of unprovoked German aggression.

[Our] land was, simply, violently, attacked...Czechoslovakia was known as a refuge for citizens of free nations and as the League of Nations' most enthusiastic supporter. There was no religious or sectarian persecution; Jews were not persecuted; nor was there racial persecution of any kind. It was truly one of the most enlightened, developed and progressive democracies east of the Rhine....The conquest of Czechoslovakia must be the destruction of the very idea of freedom in central Europe.... The whole world was willing to sacrifice Czechoslovakia. ${ }^{20}$

\section{The Occupation}

The surrender of Czechoslovakia was a political victory for Adolf Hitler. German troops marched through the conquered streets of Prague, Brno and other cities throughout the region with virtually no resistance. Some Germans welcomed the opportunity to supplant the Czech majority as the dominant presence in government, business, and politics in the newly established protectorate. Not even the continued existence of an "autonomous" Czech government provided a counterweight to the ascension of Germans within the Protectorate. However, as it turned out, occupying Czechoslovakia was easy for the Germans; establishing the supremacy of Nazi-German

\footnotetext{
${ }^{19}$ Bryant, 28-30.

${ }^{20}$ Dr. Edvard Benes, Sest let exilu a druhe svetove valky: Reci, projevy a dokumenty z r. 19381945 (Prague: Orbis, 1946) 39-41 reproduced in Orzoff, 178.
} 
Racial ideology was a much more difficult task. Nazi German intelligence failed to portray accurately the complicated ethnic, social, and economic structures of Czechoslovakia. In the wake of the German takeover, the Nazis presumed that all Germans throughout Czechoslovakia would embrace their "Aryan" identity and assume their role as the master race. However, defining who was German, what was German, and how to be German proved difficult questions to answer. The transience of identity experienced by Czechs and Germans in Bohemia and Moravia was alien, and even more so baffling, to the occupation forces. In Nazi ideology, German blood was superior. Therefore, why wouldn't these Germans, when freed from the "oppressive" Czech regime, stand and assume their rightful place at the top of the racial ladder in the region? For many Germans, there were still significant advantages to masquerade as Czechs, and for many Volksdeutsche, being German meant little more than using the German language. ${ }^{21}$

The bi-ethnic culture of Bohemia and Moravia clashed directly with the Nazi ideal. The Nazis explained human history as a continuous Darwinian struggle for supremacy amongst racial groups. At the top of this racial chain of dominance were the mythical Aryans that settled in the region of present-day Germany. True Aryans had blonde hair, blue eyes, and pale white skin. From the Aryans the chain continued down through those of Nordic influence followed by the Anglo-Saxons and Latin races. The Slavs were one of the lowest members of the Nazi's racial hierarchy (excepting Jews and Roma), preordained to be the slaves of the Aryan descendants. Because of their racial status, the Slavs inspired fear in Hitler as they could further dilute Aryan blood, or

${ }^{21}$ Chad Bryant, "Either Czech or German: Fixing Nationality in Bohemia and Moravia, 19391946," Slavic Review Vol. 61 No. 4 (Winter 2002) 685-707. 
worse create an Aryan-Slavic hybrid bent on the destruction of the German Third Reich. As early as 1925, Nazi ideologues began to visualize the necessary removal of undesirable groups beginning within the German race itself. ${ }^{22}$

In order to superimpose Nazi ideology onto the face of society, the Nazis needed an administrator, a Reichsprotektor, to direct the implementation of racial policy and Nazi ideals in the Protectorate of Bohemia and Moravia. To serve as Reichsprotektor, Hitler appointed Konstantin von Neurath, who while not a member of the Nazi Party, served the Fuhrer loyally. Neurath believed that the implementation would have to be a slow comprehensive approach and not the immediate action desired by most Nazi officials. Neurath feared a rebellion led by the Czechs of the Protectorate who continued to defy the occupation forces by displaying Czech national colors, singing nationalist anthems, and refusing to purchase German goods. Neurath permitted displays of Czech identity and reserved punishment only for the most violent, defiant acts. $^{23}$

Neurath faced significant problems when he considered how to settle the "Czech" question in the Protectorate. Nazi ideologues demanded the immediate removal of all the Czechs so that their property could be confiscated and redistributed to Volksdeutsche who returned to the Reich. Practically, this plan faced significant complications. The Reich's population experts recognized that there were not enough Volksdeutsche to replace the number of skilled Czechs in the Protectorate's industry and agriculture. Czechoslovakia possessed the booming industries necessary for the

\footnotetext{
${ }^{22}$ Vojtech Mastny, The Czechs Under Nazi Rule: The Failure of Nationalist Resistance 19391942, (New York: Columbia University Press, 1971) 21-25.

${ }^{23}$ Bryant, Prague in Black, 35.
} 
Third Reich's future war effort. Neurath summarized these findings in a memorandum dated August 31, 1940:

The most radical and theoretically most perfect solution of the problem would be the complete expatriation of all Czechs from this country and its settlement by Germans. This solution, however, is impossible because there are not enough Germans for the immediate occupation of all the territories which will belong in the foreseeable future to the Greater German Area... [A]n early realisation of the radical solution is likely to be impossible, unless one were to put up with fallow fields and deserted cities. ${ }^{24}$

What Neurath proposed in order to maintain the industrial and agricultural output of the Protectorate of Bohemia and Moravia was a radical departure from Nazi racial ideology. Instead of bloodlines becoming tainted by a singular drop of non-Aryan blood within a person's racial pedigree, Neurath argued that the special case of interracial mingling that occurred within the borders of Czechoslovakia created a Germanesque quality amongst a significant portion of the population that made them suitable for potential Germanization. This would allow the vast majority of Czechs to remain in the Protectorate and maintain the necessary industrial output for the Wehrmacht. In the same memorandum, he claimed:

Taking a close view of the population of the present Protectorate area one is surprised at the great number of fair-haired people with intelligent faces and wellshaped bodies, people who would not stand out unfavorably even in the Central German and South German area, not to speak of the area east of the Elbe River. In view of the strong mixture of blood strains with Germanic peoples during the past thousand years I consider it quite possible that for this very reason alone a large portion of the population may be allowed to remain in Bohemia and Moravia. $^{25}$

Hitler approved Neurath's plan. He approved the removal of only the most undesirable racial elements (Jews and Gypsies), subversives (communists), and the

\footnotetext{
24 "Memorandum on the Question of the Future Settlement of the Bohemian-Moravian Area," (August 31, 1940), Lesson from History, 55-56.

${ }^{25}$ Ibid, 56-57.
} 
genetically inferior (psychologically insane and homosexuals). The directives from Berlin required preferential treatment for natural born Germans, and those descended from mostly German families. The radicalized laws of the Nazi Third Reich were in this directive, as individuals were to be classified into three lettered groups. The primary "A" class group consisted of only the most loyal Germans, returning Germans who had immigrated to the Reich from Czechoslovakia, and individuals who underwent "national mutation" and swore allegiance to the Reich only. The "B" class consisted of individuals of German or Czech backgrounds who were skilled laborers, demonstrated little if any resistance to the occupation forces, and considered necessary for the future of the Reich. Only "C" class individuals, the racially inferior, communists, and other undesirables were candidates for detention, segregation, and ultimately destruction. ${ }^{26}$

Under the occupation administration of Konstantin von Neurath, the traditional Czech-German relationship maintained some degree of continuity in the Protectorate of Bohemia and Moravia. While the Nazi's dealt decisively with extreme acts of defiance, they permitted the two groups to maintain their uneasy coexistence. Disgruntled Germans and Czechs attempted to denounce other Czechs as communists, and preyed upon the property left behind by deported Jews. However, within Czech and Communist circles, resistance movements began to take hold in response to Nazi actions. These groups launched significant covert sabotage operations designed to slow the overall production of war material. These acts of defiance crippled Neurath's reputation with higher-ranking Nazi officials in Berlin. Further detracting from Neurath's authority was the presence of Karl Hermann Frank, an SS leader and Sudeten German

\footnotetext{
${ }^{26}$ Summarized from: "Proposals for the Preparation of Germanisation (National Mutation) in the Protectorate of Bohemia and Moravia," (November 30, 1940), Lesson from History,135-136.
} 
with little regard for Neurath's methods, who continuously reported the shortcomings of Neurath's leadership to Berlin. ${ }^{27}$

The final straw fell when 100,000 gallons of petroleum, the lifeblood of the Wehrmacht, was set on fire in a resistance sabotage operation. This coupled with the constant complaints from SS, Wehrmacht, and other Nazi officials led Hitler to meet with his lieutenants Himmler and Goebbels to appoint Neurath's successor. Hitler gave top priority to the effective Germanization of the Protectorate of Bohemia and Moravia, and that this new Reichsprotektor would ensure that this Germanization would provide the prototypical approach for the rest of Europe. On September 27, 1941, Hitler named one of the Reich's greatest and most enthusiastic soldiers, Reinhard Heydrich to be the new Reichsprotektor. Heydrich was the head of the Reich Security office, the founder of the Einsatzgruppen and soon-to-be architect of the Final Solution, making him the perfect leader to Germanize the Protectorate efficiently. ${ }^{28}$

Heydrich's reputation as a loyal lieutenant of Adolf Hitler was only reinforced by his appearance; he was the Nazi ideal. His blonde hair, blue eyes, and keen sense of racial superiority made him a prototypical soldier in Hitler's Nazi party. Heydrich was the founder of the Gestapo intelligence arm. He proudly embodied the racial rhetoric embraced by Hitler. Within days of his arrival in Prague, he began to challenge the existing Czech-German relationship and would forever change Czech-German Relations.

${ }^{27}$ Charles Wighton, Heydrich: Hitler's Most Evil Henchman, (Philadelphia, 1962) 15-18.

${ }^{28}$ Orzoff, 206. 


\section{The Protectorate under Reinhard Heydrich}

Shortly after his arrival in Prague, Heydrich called a meeting of the leading

German authorities of the Protectorate of Bohemia and Moravia to declare his plans for the Protectorate.

The situation in the past few weeks, as a matter of fact, has been such that one may say, the unity of the Reich was undoubtedly in danger. This region was in a situation where there was such a ferment below the surface that one can only say that it was essential to take prompt action. And I should like to say this quite openly: the fault lies not only with the enemy, it also lies with us, the Germans, because not all Germans who came to this region were imbued with the idea that this is a battlefield in which every individual German, regardless of any questions of competence, must also, in his role as a fighter, achieve the victory of the German race. Every German, who holds a leading position here, must consider himself to be a political soldier of the Fuhrer....

...This space is a heart piece of the Reich and we can never tolerate-this is demonstrated by the historical development of Germany-that the dagger blows against the Reich always come from this space...As to the final Germanisation of this space... I must have to make a register from the racial national point of view. This, therefore means that I must have the opportunity, using most diverse methods and passing through various backdoors, to screen the entire population as to its national and racial background. ${ }^{29}$

Heydrich recognized the importance of Germanizing the protectorate as it was a necessity for war material production and for the success of the Nazi racial program for the rest of Eastern Europe. Thus, Heydrich maintained a twofold mission in the protectorate. He needed to secure the industry of the Protectorate, especially the Skoda Works, against the threat of sabotage. Simultaneously, he needed to put an end to the transience of identity within the region by strictly, "scientifically" defining who was German, or candidates for Germanization, and those who needed to be cleansed from the genetic racial profile of the region. Heydrich brought a zealous determination to the position of Reichsprotektor, so he chose to accelerate the racial identification that began

29 "Part of the Short-hand Record of a Speech by the Reichsprotector, R. Heydrich in Prague," October 2, 1941. in Dolezal, 60. 
under Neurath. In the thick soup of "Czechs" and "Germans" that existed in the Protectorate, Heydrich's enthusiasm for enforcing Nazi racial ideology made him the perfect candidate to separate them. ${ }^{30}$

Heydrich ordered the Nazi SS to begin massive surveillance operations throughout the protectorate in an effort to curb resistance operations. For the most part, Heydrich viewed communist resistance organizations as the source for the worst acts of sabotage, and therefore ordered SS to focus its crackdown on communist party activities. Within the first weeks of Heydrich's administration, nearly 2,000 Czechs and Germans were tried by summary courts for actions against occupation forces, the vast majority of whom were convicted and sent to concentration camps, a few faced capital punishment for their actions. It is important to note that the Hacha government and not the SS, in fact, captured the majority of the anti-Nazi Germans rounded up during the Heydrich administration. The continued existence of the Hacha government depended entirely upon its usefulness to the German authorities. For the Hacha government, subversives were a threat to its survival. Thus, the natural antipathy between the Hacha regime and the resistance made many of these arrests possible. The Hacha government and their supporters saw the subversives as a threat to their own survival as a Nazi puppet regime. Through the use of terror by his own administration and its loyal, subservient Hacha puppet government, Heydrich maintained order in the Protectorate of Bohemia and Moravia. ${ }^{31}$

Heydrich immediately began plans to use scientific methods to categorize racially those who were German, or possessed enough German physical traits necessary for

\footnotetext{
${ }^{30}$ Wighton, 25-27.

${ }^{31}$ Whighton, 83-85, and Mastny, 77.
} 
Germanization. Heydrich equipped SS teams throughout the Protectorate with mobile x-ray labs that assisted with the classification of German or Slavic tendencies based entirely upon the shape of an individual's skull. Heydrich recognized that Neurath was right to fear a possible uprising within the Protectorate. So that Czechs would not be alarmed by the mass racial classification of society, Heydrich announced that the labs were to perform mass inoculations. As these Rontgensturmbahn units moved from neighborhood to neighborhood, they began to paint a genetic racial map for Heydrich to use in the deportation of those deemed racially unsuitable, while keeping good Germans and Germanizable Czechs in the Protectorate. In a report to Berlin, Heydrich summarized his plan to classify the entire Protectorate:

National Registration.

Independently of these measures-camouflaged under the motto of the introduction of the German Kennkarte as a domestic passport-the national registration of the entire population of Bohemia and Moravia, which alone will produce a complete picture of the percentage of those who are fit for Germanisation, is proceeding according to age groups within the framework of a medical examination.

Five mobile X-ray units-the first of which has already started operating together with the commandos made up of racial investigators from the Race and Settlement Head Office-will subject the entire population to a systematic examination and provide the scientific data needed for subsequent Germanisation. The need for the systematic anti-TB fight, which serves as an official cover, has been conveyed to the population by all available means of propaganda. $^{32}$

Heydrich approached the classification of divisions along racial lines further as he went about the maintenance of racial order with brutal bureaucratic regulatory efficiency. Already under Neurath, a 1940 Reichsprotektor decree required marriages to be approved by local officials. It further stated that any Czech female found to have sexual relations with a German man faced immediate incarceration and then transfer to

32 "From R. Heydrich's monthly report to the Reichskanzlei," (May 18, 1942) in Dolezal, 60. 
a concentration camp. The law required Czech mothers with German husbands to raise their offspring as German children. Failure to do so resulted in the incarceration and deportation to a concentration camp for the mother. Now, to ensure societal compliance with the racial legal codes, under another ruse, the Heydrich administration issued identification cards that clearly labeled Germans, Germanizable Czechs, and undesirable Czechs. Heydrich began to superimpose racial divisions within a Protectorate society that once boasted a significant population of chameleons, who utilized the transience of identity between German and Czechs. ${ }^{33}$

Heydrich's administration of the Protectorate followed a careful, methodical path toward Germanization and pacification. Whereas, in Poland, the Nazi occupation forces used indiscriminate terror to pacify the population into compliance, Heydrich utilized brutal police and bureaucratic efficiency to pacify the population of the Protectorate of Bohemia and Moravia. Within a matter of weeks, acts of sabotage and resistance became a rarity within the Protectorate. The production of materials for the Wehrmacht's war machine continued to increase, and it appeared that the Heydrich administration successfully squelched any possibility of upheaval within the Protectorate through the careful use of terror as well as carefully made concessions designed to keep industrial workers satisfied. Heydrich superimposed Nazi racial ideology upon the society of the Protectorate of Bohemia and Moravia and created a thick line that separated Czechs and Germans, which never before existed. Suddenly the

${ }^{33}$ Wighton, 100-102. 
identification of Czech or German became as simple as the letters typed on an identification card. ${ }^{34}$

\section{Legalizing Deportations, Concentration and Confiscation}

The administration of the Nazi Third Reich became a hallmark for bureaucratic documentation as paper trails for every government action could be found at the end of the Second World War. The Nazi execution of the Nuremburg Racial Laws and the Final Solution were of no exception. The Nazi authorities in the Third Reich and in the Protectorate of Bohemia and Moravia served entire households of Jews, Gypsies, and racially unsuitable Czechs with orders to clear out of certain areas within a twenty-four hour period with few or no personal possessions. Nevertheless, the bureaucratic paperwork never stopped, as confirmations of executive orders, reports of property confiscated, and subsequent deportation documents served as corroborative evidence. The Nazi approach to racial cleansing in the Protectorate of Bohemia and Moravia was not an indiscriminate round up of undesirables, but rather a carefully calculated and deliberate process.

The Nazis utilized the same legalistic approach that they patented in the German homeland. Orders for relocation that claimed to be in the "best interest" of the Jews were served with a very specific deadline. Many of the Jews still bought into the charade produced by the Nazis that they were being located to self-governing Jewish ghettos such as the one established at Theresienstadt. However, from the moment they gathered in the ghettos, the illusion was over as they were forced to give up additional personal property. The Nazis stripped these people of their dignity, forced

${ }^{34}$ T. David Curp, A Clean Sweep? The Politics of Ethnic Cleansing in Western Poland, 19451960, (Rochester: University of Rochester Press, 2006) 4-7. 
them to wear armbands to identify themselves, and appropriated their property for use by other Germans or the Third Reich. This legacy of separation, concentration, and deportation to camps became the blueprint for population transfers at the end of the Second World War. ${ }^{35}$

\section{Benes Abroad}

As the Nazi authorities in the Protectorate of Bohemia and Moravia under Konstantin von Neurath and then Reinhard Heydrich consolidated their control, Edvard Benes was not complacent abroad. When the Czech government-in-exile began to take shape in London during 1940, Benes took an immediate leadership role and ultimately became its president. For some Czechs, Benes remained stained by the international stigma of his apparent failure to challenge the decisions of the Munich Conference that sought to appease Hitler, despite the fact that the West had more or less forced him to accept the agreement. This, in combination with the legal necessity of reestablishing Czechoslovakia's territorial integrity, made Benes' first critical policy endeavor amongst the Allies, the nullification of the Munich Agreement. Benes lobbied heavily with the leadership in Britain for the nullification of the Agreement. While this did not happen until the middle of 1942, the Allied governments of the Soviet Union and Great Britain, along with the then neutral United States recognized the Czechoslovak Government-inExile, and began formal diplomatic relations with it. ${ }^{36}$

Benes succeeded in his resumption of the role of President in the now recognized Czechoslovak government-in-exile. He then turned his attention to the issue of prewar Czechoslovakia's German minority. Having been one of the chief proponents

${ }^{35}$ Timothy Snyder, Bloodlands: Europe Between Hitler and Stalin, (New York: Basic Books, 2010) 310 .

${ }^{36}$ Douglas, $34-35$ 
of a legally minimized role in government and administration for the Sudetendeutsche, Benes began to lobby for, at the minimum, partial removal of the Sudetendeutsche from postwar Czechoslovakia. Early in 1940, communications provided by the Czech underground indicated a growing sentiment within the Czech community that any postwar peace would require the forced removal of Germans from Czechoslovakia. Throughout the end of 1941 , Benes began to declare publicly the need for a solution to punish the Germans of Europe and redraw the ethnic map of central and Eastern Europe in the interest of a lasting peace. In an article in Foreign Affairs, Benes declared, "It will be necessary after this war to carry out a transfer of populations on a very much larger scale than after the last war." Similar sentiments were expressed by the Polish government-in-exile that also declared its desire for a lasting peace based upon the removal of its own German minority. ${ }^{37}$

The Allied leadership frowned upon Benes' public declarations for the need of population transfers at the end of the war. At the time, the unconditional surrender of Germany appeared a distant hope. The Soviet Union and United States had only recently entered the war; its course was far from certain. The British maintained hopes that they could foment rebellion within the Third Reich, and Benes' sabre rattling served only to supply Goebbels with an unending string of propaganda to mobilize Germans throughout occupied Europe. Western public sentiment was far from in favor of population transfers that violated basic rights. Without a radical change in public opinion, Benes' would be forced to consider other, "alternative" transfers within Czechoslovak borders, creating ethnic German enclaves within the Czechoslovak state.

${ }^{37}$ E. Benes, "The Organization of Postwar Europe," Foreign Affairs Vol. 20 No. 2 (January 1942) 237-238; and Sarah M Terry, Poland's Place in Europe: General Sikorski and the Origin of the Oder=Neisse Line, 1939-1943, (Princeton: Princeton University Press, 1983) 52. 
Unwittingly, Benes set the gears into motion that ultimately made the forced deportation of millions of Germans possible.

\section{The Assassination of Heydrich and the Nazi Retaliation}

Benes understood that Machiavellian power calculations dictated the nature of wartime politics, and therefore, he demanded that the Czech resistance demonstrate the Czech people's willingness to pay any price to defeat the Nazis. These actions could provide Benes with invaluable political capital, which he could then use to leverage the Allies into approval of his postwar plans. In weekly radio addresses, Benes incited his people to take actions to sabotage or frustrate the Nazi occupational forces. When Benes secured British recognition for the provisional Czech governmentin-exile, he authorized Czech security agents attached to the British Intelligence service to begin plans to parachute operatives into the Protectorate of Bohemia and Moravia to commit additional acts of sabotage. On the surface, these acts served as signs of resistance toward the occupational forces, but they also served Benes larger political agenda. $^{38}$

The appointment of Reinhard Heydrich to the position of Reichsprotektor and the subsequent pacification of the Protectorate enraged Benes. The Allied leadership questioned the loyalty of the Czechs to the cause and shunned Benes. It was out of this frustration that the plan to assassinate Reinhard Heydrich was born. In January of 1942, Czech agents were dropped into the Protectorate under orders to kill Heydrich. Kept in the dark about this mission until the last minute, underground resistance leadership pleaded with the agents and with the Benes government to cancel the plan.

\footnotetext{
${ }^{38}$ Benjamin Frommer, National Cleansing: Retribution against Nazi Collaborators in Postwar Czechoslovakia, (Cambridge: Cambridge University Press, 2005) 30.
} 
The leadership on the ground understood what the ramifications of assassinating one of Hitler's most prized lieutenants would be, and even Benes' communist counterpart, Klement Gottwald, declared the folly of such an attempt on Heydrich's life. Despite the constant pleas from the resistance movement inside the Protectorate, Benes remained steadfast in his conviction that the assassination of Heydrich would make the Allies sympathetic to the Czechoslovak government. Benes issued an order declaring that the operation would be in the best interest of the Czechoslovak people. On May 27, 1942, the Czech agents launched the attack on Heydrich's car, mortally wounding him. ${ }^{39}$

For Hitler, the assassination of Heydrich served as confirmation of his own inclination to answer resistance with utmost brutality, and he demanded immediate reprisals against the Czechs. Heydrich's second-in-command, Karl H. Frank, took control of the situation in Bohemia and Moravia, but slowly executed the Fuhrer's orders. Frank, perhaps the most knowledgeable Nazi official in the Protectorate, understood that brash action could very easily foment rebellion in the Protectorate and cripple the Wehrmacht's operation on the eastern front. So long as Heydrich lived, Frank satiated Hitler by promising to pursue the individuals responsible along with anyone connected with the plot. However, when Heydrich eventually died from his wounds, Hitler renewed his call for retributive acts of extreme violence. The collaborationist Czech government rounded up and tried four thousand members of the resistance, and sentenced fifteen hundred of those to death. This was not enough of a reprisal. Hitler demanded that an example be made of the Czechs so that no occupied people dared to assassinate its ruling Nazi officials. Hitler ordered Frank to pick an isolated village that had few industrial workers for total destruction. SS Einsatzgruppen

\footnotetext{
${ }^{39}$ King, 185-186.
} 
were to execute the male inhabitants of the city on the spot, women were to be gathered and deported to concentration camps, and children were to be separated into those who were Germanizable and those destined for concentration camps. The village was then to be razed to the ground so that no record of its existence would be found. For this act of reprisal, Frank chose the village of Lidice for its optimal effect, because of its short distance from Prague. ${ }^{40}$

The aftermath of the assassination of Reinhard Heydrich left the Czech nationalist resistance decimated. The majority of its leadership, and most skilled agents were either dead or imprisoned in Nazi concentration camps. Communists that were uninvolved in the plot were captured based on their interactions with nationalist resistance figures. For the remainder of the war, the Czech resistance was practically non-existent. In the boastful words of Karl $\mathrm{H}$. Frank in his summation report of the retaliation for the assassination:

After the civil state of emergency, imposed as a result of the assassination of SSObergruppenfuhrer Reinhard Heydrich, was raised in the Protectorate of Bohemia and Moravia on July 3, 1942, the greater part of the population has calmed down considerably. The measures taken during the civil state of emergency:

1. Arrest of 3,188 Czechs

2. The shooting of 1,357 Czechs following death sentences passed by Courts Martial in Prague and Brunn,

3. The razing of two Czech Villages Liditz (95 houses) and Lezaky (8 houses),

4. Discovery of the perpetrators and death of the assassinators after a severe fight

Re-established peace and order in a short time and made the armaments contribution and harvest in the Protectorate secure.

The maintenance of the present political line, that is:

Firm action, individual political measures taken, the emotional atmosphere artificially produced by us and the wearing down of the nerves of the Czechs according to plan, things which increased the fear of the population to the point of

40 "Report by Dr. Geshke on the Destruction of Lidice, June 24, 1942," in Dolezal, 70-71. 
giving rise to rumors about a forthcoming decimation of the entire nation-proved to be correct. $[\ldots]^{41}$

Internationally, Benes received in exchange for the lives of hundreds of Czechs, the exact power he wanted. The draconian measures implemented by the Nazi's in retaliation for the assassination polarized Czech society along the very ethnic divisional lines that the Nazis helped to create. The call went out to remember Lidice, and the lives crushed by the tyrannical Nazi regime. Until the end of the war, very little was asked of the Czechoslovak people by the Allied leadership because they had already paid a heavy price. Benes publically declared on many occasions that the presence of Germans in the Sudetenland would be an impediment to lasting peace. The Czechs on the ground in the Protectorate were left at the mercy of Karl H. Frank with little or any protection provided by the government-in-exile in London or the Czechoslovak Communist leadership in Moscow. ${ }^{42}$

\section{The Occupation after Heydrich}

The appointment of Karl Herman Frank as Heydrich's successor left the Protectorate under yet another brutal Reichsprotektor. The SS continued its reign of terror by holding every citizen of the Protectorate responsible of even the most seemingly benign actions. The citizenry of the Protectorate actively assisted the SS by denouncing neighbors and family members for personal gain. Once a neighbor or family member was arrested, his or her property came up for grabs, thus making denunciations economically advantageous for the general population. ${ }^{43}$ Under Frank,

\footnotetext{
41 "Report to the Fuhrer for the period from May to September 1, 1942" in Lesson from History, 144

${ }^{42}$ Douglas, 42.

${ }^{43}$ David D. Kelly, The Czech Fascist Movement, 1922-1942, (Boulder, Co: Eastern European Monographs, 1995) 121.
} 
the industrial output of the Protectorate of Bohemia and Moravia reached record highs, and solidified Frank as the undisputed Nazi leader in the region. The only significant change that occurred under Frank was the easing of pressure for the execution of racial cleansing in the Protectorate. The changing tides of the war led the Nazi Leadership in Berlin to call for the redirection of all resources in support of the total war effort. In preparing the German people for the brutal war of attrition following Stalingrad, Joseph Goebbels redirected the focus of the population to the cause of the war:

...now they can see the underlying cause: rich peoples, led by a refined and insatiable plutocracy and its most radical offshoot, Bolshevism, overloaded with territorial possessions and raw resources, have forced the German people along with the Axis powers to take up arms to decide the vital issue of whether in future we will have an adequate basis for our national life, or even lose the completely insufficient basis for this which we already possessed. [...]

Every birth brings pain. But amid the pain, there is already the joy of a new life. It is a sign of sterility to shy away from new life on account of the pain... Our age too is an act of historical birth, whose pangs carry with them the joy of richer life to come. The significance of the war has grown as its scale has increased it is relentlessly at work, shattering old forms and ideas, and directing the eyes of human beings to new, greater objectives... In an age which like never before offers us the choice between the highest fortune and deepest catastrophe of our Reich, we stand firm as a people, determined and ready to work and fight so as to fulfil ( $\mathrm{sic}$ ) the ultimate meaning of the war. ${ }^{44}$

As the leadership in Berlin provided new impetus for production in the execution of the war, Frank immediately reallocated his resources. He discontinued pursuance of Heydrich's racial categorization in favor of redoubling efforts to increase industrial output. Courts-martial sentenced thousands to death or hard labor in concentration camps. Frank knuckled down on the population of the Protectorate, and transformed the Czechs of the Protectorate into a vital war human resource for the German war effort. Germanizable Czechs were considered prime candidates for conscription into

${ }^{44}$ Joseph Goebbels, "The True Meaning of the War," in Roger Griffin, Fascism: Oxford Reader, (New York: Oxford University Press, 1995) 158-159. 
the military services. The Third Reich also utilized other portions of the Czech population as well as other eastern peoples as forced laborers in wartime industries, as well as in industries necessary for the survival of German non-combatants on the home front. These slave laborers as well as those employed in the all-important industries of the Protectorate formed part of the backbone of German war production throughout the remainder of the war and presented problems for the government-in-exile in London and its communist counterpart in Moscow. ${ }^{45}$

By late 1944, Frank's continued suppression of resistance within the Protectorate proved that the Allies had very short memories when it came to the loss of Lidice. The lack of an attention-grabbing act of resistance as the tide of the war turned left questions in the minds of the Allied leadership. Were the Czechs doing enough to resist the leadership of the Protectorate, or were they, in fact, collaborating with the Nazis? For Benes and Gottwald, the argument remained that the Nazi retribution for the assassination of Heydrich had destroyed the infrastructure and leadership necessary for large organized acts of overt sabotage. Due to this, Czech acts of resistance manifested themselves as work slowdowns, minor incidents of sabotage (broken tools and instruments), and expressions of support for resistance provided in the privacy of Czech homes. ${ }^{46}$

The struggle between Frank's security forces and Benes and Gottwald's supporters came to a head in the final throes of the Second World War. As the Soviet Red army broke through German lines near the eastern Czechoslovak border in March

\footnotetext{
${ }^{45}$ Igor Lukes, Czechoslovakia between Stalin and Hitler: The Diplomacy of Edvard Benes in the 1930s, (Oxford: Oxford University Press, 1996) 79-82; and Edward L. Homze, Foreign Labor in Nazi Germany, (Princeton: Princeton University Press, 1967) 121-127.

${ }^{46}$ Frommer, 20-21.
} 
1945, they began to march on Prague. At the same time, American forces under General George S. Patton closed to within twenty miles of the state capital. Benes and Gottwald each pleaded with the Allied leadership, and specifically with Stalin, for the two armies to allow the Czechs to revolt against the Nazi occupation forces and free Prague. Reluctantly both armies stopped short of the city and waited for the remnants of the Czech national and communist resistance forces to revolt. On May 5, 1945, the revolt was launched as Czech forces attacked entrenched German positions throughout Prague. For the Germans of the city, their worst fears were realized. They read reports from the Eastern Front declaring what came with revolt and the Soviet Red Army. ${ }^{47}$

...The supply and rear guard detachments that follow [the front lines] systematically loot every house under the eyes of tolerant officers....Reports from eyewitnesses and other sources attest to extensive occurrence of rape, usually under the influence of alcohol, Girls and women of all ages from 8 to 68 years old are violated, sometimes by up to 24 officers and Red Army regulars at a time... it is clear that enemy troops fire indiscriminately at the civilian populations... ${ }^{48}$

The rout of Nazi occupation forces that followed the Prague uprising left the Sudeten Germans as well as other German nationals at the mercy of the liberating and revolutionary forces. In victory, the Soviet Red Army responded as conquerors, they pillaged and raped women of all ages in the liberated territories of Ukraine, Belorussia, Poland, and the former Third Reich. These liberated populations then launched their own campaigns of retributive violence against Germans as well as their own plans of deportations back to the territory of the former Third Reich. However, in addition to this, the Czechoslovak government-in-exile, in collusion with its communist

${ }^{47}$ Giles MacDonogh, After the Reich: The Brutal History of the Allied Occupation, (New York: Baskic Books, 2007) 128.

${ }^{48}$ Alfred-Maurice de Zayas, A Terrible Revenge: The Ethnic Cleansing of the East European Germans, 1944-1950, (New York: St. Martin's Press, 1993) 48-50. 
counterparts, placed their own plans intended to end rather than renew the traditional prewar Czech-German relationship. Their methods inspired by the actions of other states in the Twentieth Century including the Greco-Turk population exchange of the 1920s and the activities of the Nazi regime in the Protectorate would redraw the ethnic map of Central Europe further at the end of the Second World War.

\section{Planning the Expulsions}

In the aftermath of the destruction of Lidice, Benes intensified the rhetoric of deportations. In multiple speeches, he argued that the Germans of Central Europe were inherently a group bent on subterfuge, war, and destruction. Thirty years and two world wars proved that the German people failed to appreciate the gravity of the chaos and destruction they had created. Benes urged the allied governments to redraw the maps of Europe along ethno-racial boundaries because, as he contended, the presence of ethnic minorities within nation-states created the political unrest that was ultimately the source of war. In other words, the deportation of Czechoslovakia's Sudetendeutsche and other Volksdeutsche from throughout Eastern Europe back to the German heartland was in the interest of a lasting peace on the European Continent. While the responsibility of the Volksdeutsche and Sudetendeutsche for the war can be debated, blanket responsibility cannot be assigned to any one ethnic or racial group. ${ }^{49}$ Even before the assassination of Reinhard Heydrich, Benes struck a blow against collaborationist Czechs and Germans. In January 1942, Benes made his first strike against collaborationist Czechs and the minority German population. Czechoslovakia, along with Poland and other governments-in-exile present in London

\footnotetext{
${ }^{49}$ Norman M. Naimark, Fires of Hatred: Ethnic Cleansing in Twentieth-Century Europe, (Cambridge: Harvard University Press, 2002) 114.
} 
signed the St. James Declaration. The declaration, signed a year later by the United States and United Kingdom, became the legal basis for war crime tribunals, and more explicitly, the Nuremburg Trials. The governments, which signed this agreement, agreed in principle to seek out, incarcerate, expedite, and to punish all Nazi war criminals. This included all international war criminals no matter their race or nationality. In the case of Benes and Czechoslovakia, the question of guilt or responsibility expanded to include any actions that could be construed as support for or compliance with the Nazi administration of the Protectorate of Bohemia and Moravia. The Germans were, in effect, collectively responsible for the actions of Nazi Germany. ${ }^{50}$

Following the destruction of Lidice, even the most skeptical among the Allied Leaders began to approve of Benes' plans to pursue "humane" population transfers. When the Allies raised any questions about the expulsions' humanitarian implications or legalities, Benes would hammer upon the legality and humanitarian implications of the destruction of Lidice. Even more important for the Benes government was the outcry expressed in the American and British Press over the massacre. The New York Times and the Economist ran multiple accounts of the incident that swayed public opinion in favor of the Benes Government. Suddenly, for many in the European Theatre of War, "Remember Lidice" became a rallying cry that mirrored its American counterpart "Remember Pearl Harbor."

Leadership within the Labour Party led British Government, as well as leaders within other Allied governments responded to Benes' plan to transfer the minority

\footnotetext{
${ }^{50}$ MacAlister Brown, "The Diplomacy of Bitterness: Genesis of the Potsdam Decision to Expel Germans from Czechoslovakia," The Western Political Quarterly, Vol. 11 No. 3 (September, 1958) 607-613.

51 Douglas, 39.
} 
populations from Czechoslovakia with open arms. Within the party's plans for postwar resettlement, the party planners declared that the end of the Second World War presented the Allied governments with a rare opportunity to redraw the ethnic lines of Europe that historically lacked definition. The party platform went so far as to declare that "The organised transfer of population in the immediate post-War period, may, indeed, be one of the foundations of better international relations in a later phase. Nor would this be a new departure." The British parliament and particularly the Labour Party members bought into Benes' claim that the repatriation of Germans throughout Eastern Europe was in the best interest of a lasting post-War peace. ${ }^{52}$

With international support for Benes' postwar aims shored up, the Czechoslovak Government-in-Exile in London and its communist counterpart in Moscow became places of significant contention over the nature of postwar deportation and other retributive policies. Klement Gottwald and his communist allies in Moscow demanded harsh punishments for members of the bourgeois elite from all ethnic backgrounds who opportunistically collaborated with or at the very least failed to resist the German occupational forces. For the Benes government-in-exile, the primary concern was to capture all collaborators, as well as secure the removal of the majority of Germans through deportations. National committees and tribunals would deal with German criminals prior to deportation. Czech collaborators who denounced their neighbors to the Nazis, aided or abetted the enemy, or collaborated in the interest of personal gain faced investigation, arrest, and trials under the new Czech administration. Most of them would be tried and convicted as traitors as retribution for the destruction of the

\footnotetext{
52 Labour Party, National Executive Committee, International Postwar Settlement, (January,
} 1945) 5 . 
resistance. The resistance members who remained demanded their chance for vengeance. No matter the disagreements between Czech nationalists and communist, between Benes and Gottwald, they all agreed that those populations and members of populations that collaborated with the Nazi occupation forces must pay for their actions against the Czechoslovak state. ${ }^{53}$

The final necessary measure to ensure that Benes had a relatively free hand in dealing with ethnic matters within Czechoslovakia was to secure Joseph Stalin's complete support for the deportations. Under Masaryk, Benes had been an ardent nationalist who was a dyed-in-the-wool anti-communist. By 1943, however, Benes recognized that the Red Army would liberate Czechoslovakia. The Pragmatic Benes traveled to Moscow where he feigned an interest in communism and won over Stalin's support for a reconstituted Czechoslovakia as well as his support for the deportation of the Sudetendeutsche. As the Soviet Red Army rolled westward, and reports of its atrocities against the Germans followed in its wake, Benes knew that the Red Army would put up little or no resistance to his plans for Czechoslovakia's Germans. ${ }^{54}$

From the time of his resignation following the Munich Conference, Edvard Benes faced a future tainted by the stigma of his failure to protect his nation. The failed international attempt to satiate Hitler's appetite for Lebensraum ultimately left most leaders involved, including Chamberlain, to careers of memoir writing. For Benes, however, it meant a redoubled effort to rewrite his past and reestablish himself as the uncontested leader of Czechoslovakia. With his leadership and state reestablished, Benes set out to create the political capital necessary to secure allied support for his

\footnotetext{
${ }^{53}$ Brown, 615-620.

${ }^{54}$ Frommer, 28-29.
} 
postwar plans for Czechoslovakia. In ordering the assassination of Reinhard Heydrich, Benes set the wheels into motion that would deliver Allied support for his planned postwar forced transfer of millions of Germans from the former Protectorate of Bohemia and Moravia into the postwar confines of Germany. Benes set the stage not for the next step in the Czech German relationship, but rather for the end of the relationship through the elimination of one of the participants. 


\section{The End of the War}

\section{The Wild Times}

As early as the 1942 signing of the Saint James Declaration, Benes began a radio propaganda campaign designed to ignite the simmering embers of Czech-German hatred in the Protectorate. Benes incited the civilian populations of Czechoslovakia to seek out their own vigilante justice against collaborators and traitors. This did very little to rouse the resistance of the Czechs for most of the war, but the arrival of the Red Army in 1945 changed the scene. As the rigid, extra-legal structures of the Protectorate of Bohemia and Moravia disappeared when the Red Army rolled through the area; a political vacuum emerged in its wake leaving little to govern the actions of the liberated populations. In anticipation of the liberation, Benes planned his return to Czechoslovakia by way of Moscow.

In early April 1945, the principle leaders of the Czech Nationalist and Czech Communist resistance groups met in the liberated city of Kaschau to establish temporary political and legal structures to take hold in the wake of the Red Army's advance. Though Klement Gottwald and Edvard Benes were not present, each leader forwarded his agenda to the meeting in order to ensure his own influence over the liberated territories of Czechoslovakia. Both the nationalists and the communists agreed in principle to a program that would govern the liberated territories until a provisional government could meet to prepare for the reestablishment of a permanent Czechoslovak government. The directives issued in Kaschau pertained to the creation of a Czechoslovak military force from units that were already attached to the Soviet Red Amy, recognition of the Soviet Red Army's role in the liberation of the Czechoslovak 
state, and the treatment and punishment of collaborators as well as the Volksdeutsche and Magyar minorities. ${ }^{55}$

The Kaschau Program of April 5, 1945 created an interim national government for the territories of Czechoslovakia freed by the Red Army. In Section V of the program, the representatives of the first cabinet council established a new system of government by popularly elected national committees. However, the section only declared that there would be popular non-partisan elections without any direction as to how these elections would be organized. The program empowered these national committees to supervise and administer their geographical regions with only nominal supervision provided by the national government that President Edvard Benes directed by decree. The cabinet focused the power of the state mainly in the local national committees as authorized by the President. The cabinet directed the national committees to secure the capture of any individual believed to have collaborated in some manner with the Nazi occupying forces. The program did not provide a litmus test for national loyalty, so each committee created its own criteria for demonstrated loyalty to Czechoslovakia or traitorous actions on behalf of the Nazi Third Reich. Ultimately, the wide range of interpretation of these laws led many national committees to convict individuals of collaboration based partly, if not predominantly, on ethnicity. ${ }^{56}$

Section VIII of the Kaschau Program further invoked ethnically motivated criteria. The section began with a declaration of solidarity amongst all Czechoslovaks for their suffering at the hands of citizens (German, Slovak, Czech, and Magyar) who

\footnotetext{
${ }^{55}$ Frommer, 58.

56 "The Kaschau Programme-Programme of the new Czechoslovak Government of the National Front of Czechs and Slovaks, accepted at the first cabinet council held on April 5, 1945," in Schieder, 181.
} 
collaborated with the Nazi Occupation forces. Then, this section of the program peculiarly declared that, "The Republic has no wish to persecute its loyal German and Magyar citizens, and they, and above all those who proved their faithfulness even in times of great difficulty, will be unaffected." However, the program went on to define citizenship for the minorities of Czechoslovakia by singling out Germans and Magyars.

Czechoslovak citizenship for Germans and Magyars who held it before Munich 1938 will be confirmed and the possibility of their return to the Republic will be assured only if they were anti-Nazis and anti-Fascists, if they fought against Henlein and the irredentist Magyar parties for the Czechoslovak Republic in the period before Munich and if, after 15 March, they were persecuted for their resistance, their struggle against the regime then in power and their loyalty to the Republic by the German and Magyar official authorities, were thrown into prisons and concentration camps or had to flee abroad from the German or Magyar terror, where they actively participated in the struggle for the restoration of Czechoslovakia.

Czechoslovak citizenship of other Czechoslovak citizens of German or Magyar nationality will be cancelled. Although they may again opt for Czechoslovakia, public authorities will retain the right of individual decision in the case of each application. Those Germans and Magyars who have been prosecuted and condemned for a crime against the Republic and the Czech and Slovak people will be declared to have forfeited their Czechoslovak citizenship and, unless they are under sentence of death, will be expelled from the Republic for ever.

Germans and Magyars who immigrated into Czechoslovak territory after Munich, 1938, will, unless liable to criminal proceedings be forthwith expelled from the Republic, with the exception of those who worked on behalf of Czechoslovakia. $^{57}$

Sections VIII, IX and X of the Kaschau Program made it very clear to the national committees that only "loyal" members of these minorities would be permitted to remain in postwar Czechoslovakia. Once again, the vagueness of the law led to a simple question, how could an ethnic German or Magyar prove his or her loyalty? Moreover, in this and other government documents created immediately following the liberation, there are mentions of loyal Germans, and yet for the most part in practice being

57 "The Kaschau Programme," in Schieder, 183. 
German was equated with being a collaborator. In the Nazi Protectorate of Bohemia and Moravia, the question of citizenship became one of historical and scientific proof of one's lineage and genetic purity. To make this identification easier, Reinhard Heydrich had established a complex system of Reich passports to indicate the social and racial status of an individual. In the Benes' postwar Czechoslovakia, Germans and their Magyar counterparts faced an even more significant challenge, proving through evidence provided by neighbors and family members that an individual did nothing to support or even merely approve of the Protectorate of Bohemia and Moravia or the Hungarian occupation authorities in their zone carved out of prewar Czechoslovakia. The message to the national committees from Benes and Gottwald remained clear. The presence of Germans and Magyars destabilized the region prior to the war, so in the interest of peace they needed to be forced out of postwar Czechoslovakia. ${ }^{58}$

As Benes's and Gottwald's representatives met to create an immediate postwar government, in regions throughout the Czechoslovak state, retribution against

Germans, whether they had collaborated with the Third Reich or not, began in earnest. Reports from across eastern and central Europe recorded the ferocious assault of the Soviet Red Army as well as that of the newly liberated populations on ethnic Germans. The Soviets raped, plundered and pillaged as they drove back the Wehrmacht terrorizing the Volksdeutsche as they went. One German farmer's wife in Seiferdorf gained an immediate appreciation for the nightmare that liberation brought for the German minority in Czechoslovakia.

A very restless time began for us on 5 May 1945, when the Russians occupied our region. Right on the first evening, our nieces who lived with my mother-inlaw as refugees in the annex of the farm, came running breathlessly and begged

58 “The Kaschau Programme," in Schieder, 184-187. 
us to hide them as otherwise they would be raped by the Russians. That was only the beginning. Very few young girls were to be seen after this. They hid wherever possible; no woman was safe from the Russians, not even older ones. $^{59}$

The Soviets were not the only source of fear as the Wehrmacht retreated. The Czech resistance began its own campaign of vengeance against the Germans that were left behind. Individuals seeking to settle their own scores with neighbors and collaborators prowled the liberated streets armed with sticks, rocks, pistols, and rifles. Men, who sought revenge against any German they could find, would pose as officers of the law, shoot those who resisted, and arrested many based entirely upon their identification as German. The Kaschau Program's national committees became vigilante committees made up of members of the resistance, who established summary courts that meted out retribution at alarming rates. Germans, regardless of their actions during the Nazi occupation, were charged with collaboration, generally on the biased testimony of some wronged neighbor. If a sentence of capital punishment was pronounced, the prisoner would be shot later that same day. Due to the influx of charged individuals, the national committees' courts established impromptu prisons in homes, former ghettos, and concentration camps to hold the prisoners. In these camps, guards coerced confessions from the prisoners through torture, and put them to death before they could be tried in court.

Apart from the drinking bouts, the guards' orgies with interned women, and the torture during interrogations, there were regular executions. Some guards even invited their friends to watch. After attempts to kill by 220 -volt electric current did not succeed, death was by hanging...Everyone who was to be executed was first tortured until he signed the confession he was given. ${ }^{60}$

\footnotetext{
59 "Report of the Experiences of Elisabeth Pechke, farmer's wife, of Seifersdorf, district Jagerndorf," Original, dated 17 April 1947, typewritten, 10 pages, as published in Schieder, 415418.

${ }^{60}$ Frommer, 56.
} 
Officially, the national committees sought to reuse the Nazi-created concentration camps as prisons and collection points for minority Germans and those accused of collaboration. Due to the desperation of the national committees for guards in these reassigned concentration camps, former concentration camp internees often performed this duty, which gave them an opportunity for revenge. The conditions within these "prisons," and the acts of debauchery committed within, made imprisonment a most dreaded fate. One of the most infamous camps staffed first by the Nazis and then by the Czechs was Theresienstadt, which became a prison for notorious former members of the SS and Waffen SS. Some zealous Czech nationals did away with all pretense of legality, rounded up all the Germans from the surrounding area, and placed them in impromptu prisons created from barns, garages, and industrial plants. For one young German girl who attempted to escape from the hands of the Soviets, but was captured by her Czech neighbors, the nightmare of imprisonment took the following form:

Once there [on a large Czech estate], we were arrested and locked into storage sheds, treated and guarded like hardened criminals. $90 \%$ of the people were elderly, women and children..."Food" was available in pig troughs. Whoever sought to collect something edible while out in the fields [working] was immediately shot...Night after night we were handed over to the Russians-What they did to us was indescribable! $!^{61}$

Under the guise of capturing traitors and collaborators, some Czech national committees concentrated the German population present in their jurisdiction in preparation for their deportation. Just as the Nazi Third Reich provided Jews, Roma, and others with careful documentation of orders to vacate their homes for the purpose of relocation, and ultimately, the legal confiscation of all of their property by the state, the Czechoslovak national committees did much the same. During the chaos in the

${ }^{61}$ de Zayas, $A$ Terrible Revenge, 90-91. 
aftermath of liberation, the Czech national committees served thousands of Germans with legal documentation demanding that they immediately vacate the premises in preparation for transportation to Germany. The orders were succinct in June of 1945:

You and your whole family are required to be ready before 10 a.m., 18 June 1945, to depart from the territory of the CSR. Each person may take with him a maximum weight of 30 kilograms of luggage. The summons for departure will follow tomorrow and before this summons arrives, you may not leave your residence.

I draw your attention to the fact that any damage, destruction, etc. of the property and installations of your household could even be punished by death. This expatriation is taking place in complete agreement with Russian Army Headquarters. The persons concerned are to assemble in Habartice in front of Kretscham Restaurant at 11 a.m. ${ }^{62}$

By July of 1945, the national committees refined their orders for expulsion by itemizing the items that the committee permitted Germans to carry with them to the occupied zones of Germany. While this itemized list appeared to allow the Germans to keep much of their personal belongings in their possession, the truth was that the majority of the items would be confiscated or stolen before arrival in the German occupied zones. The precision that characterized these orders were eerily reminiscent of those issued during the German occupation. ${ }^{63}$

\section{Notice}

Mr. Leopold Pfitzner and all members of his family Landskron, Schillerstra $\beta$ e 506

In accordance with the resolution passed by the Administrative Commission of the town of Landkron [National Committee], you are required to be present in the Market Place at 7 a.m., 5 July 1945, for the purpose of being expelled from the Czechoslovak Republic.

For this purpose you may take the following articles with you:

1. Food, as much as you can carry, at least 7 days ( sic) supply;

62 "Okresni spravni komise ve Frydlante v. C." 15 June 1945, as translated in Schieder, 309. 
2. Clothing (the bare necessities);

3. Washing materials (soap, toothpaste and toothbrush, etc.);

4. Underwear, children's underwear, bedding;

5. Money, securities, deposit books, etc.;

6. Jewelry;

7. Perambulator

You are further allowed to take a hand-barrow with you for transport.

You have to leave your residence in perfect order. Non-Compliance with this notice will be punished.

There is no appeal against this notice ${ }^{64}$

As the committees' continued the concentration of the Germans in

Czechoslovakia, they also began to consider the methods necessary to transport the expellees to the German border. This conundrum was created by the aftermath of the war. Allied bombing and other military operations left many of the bridges, roads, and railroads that connected Czechoslovakia and Germany non-traversable. The concentration camps, or deportation camps, quickly reached their maximum capacity and continued to grow. This led many of the committees to endorse forced marches to the German border in order to expel the Germans that were currently incarcerated as well as those given orders to vacate. These marches, of men, women, children, and the elderly resulted in the deaths of thousands. While sources disagree over the number and severity of these marches, they devastated the individuals who experienced them. Here is a description of one such instance:

At 5 a.m. on 13 May, the marching order was given. A few carriages were available for old and sick persons and for babies, but not by any means enough to transport all those who were in need. As it was, the camp had been mainly filled with women and children and old people.... It was terribly hot, the original closed marching column got more and more drawn out, some old and sick persons had to rest more and more often until they could not get any further. Many of them died in the ditches either from exhaustion or simply killed by the accompanying Revolutionary Guard [Czech Guards]....

...On the way Russians came and selected what they liked: suitcases, bags and whatever was left, and most of all-women. Between 2 a.m. and 5

64 “Expulsion Notice from Landskron," in Schieder, 308. 
a.m., we were allowed to rest in the ditches along the road, but we found no peace. Then we went to Konigsaal (Zbraslav), where the harassed people were assembled in a large meadow. I was told by a member of the Polish Red Cross, who served amongst the Czech guards, that of some 1,300 people who had started on this march from Pribram, some 300 had not survived it. ${ }^{65}$

The Kaschau Program provided the national committees with far-reaching interpretive powers to determine what actions constituted collaboration with the Nazi occupation forces and the administration of the Protectorate of Bohemia and Moravia. For most of the committees, identification of an individual as Sudetendeutsche or that person's failure to demonstrate any participation in resistance activities resulted in expulsion or imprisonment. The preponderance of evidence presented in the courts created by the national committees most often took the form of unreliable eyewitness testimony. While the testimony of a fellow Czech patriot on multiple occasions resulted in acquittal, more often than not it provided Czechs with the opportunity to denounce neighbors based upon selfish quarrels, greed, or jealousy. Just as the Nazi occupation forces became entangled in petty local rivalries, the national committees became an instrument with which individuals could mete out their personal forms of vengeance. For President Edvard Benes, the international community began to exert greater pressure to limit action in the liberated territories to the capture and punishment of proven Nazi collaborators. ${ }^{66}$

\section{The Great Decree}

In an attempt to "reign in" and focus the unbridled retribution of the national committees, President Edvard Benes issued the Great Decree on June 19, 1945 to provide central government direction to the local national committees. The Great

65 "Report of the experiences of Dr. Korkisch, University Lecturer, of Prague," Original, dated 2 March 1947, handwritten, 8 Pages, as published in Schieder, 110.

${ }^{66}$ DeZayas, A Terrible Revenge, 67. 
Decree established the legal definitions for indictments of individuals based upon the specific circumstances of their accused crimes. It also established a network of national criminal courts to try anyone accused of the crimes outlined within the decree. Benes originally meant for the great decree to govern Czechoslovak legal precedent for three months, it ultimately remained in force for the next two years. ${ }^{67}$

The preamble to the Great Decree declared the intentions of the Czechoslovak government in its pursuance of "justice". From its outset, the Great Decree demonstrated that the pursuit of justice was, in fact, the exercise of retribution against anyone perceived to have participated in or cooperated with the Protectorate administration. The nature of the document was not to provide fair and impartial justice but rather a justice inspired by and pursuant to vengeance.

The Shocking crimes committed by the Nazis and their treasonous accomplices in Czechoslovakia call for stern justice. The oppression of the homeland and the murder, enslavement, robbery, and humiliation to which the Czechoslovak people were subjected, and all of the extreme German barbarities, in which, regrettably, traitorous Czecholovak citizens also took part (including some who abused their high office, mandate, or rank), must be punished without delay in order to eradicate completely the Nazi and Fascist evil...68

The Great Decree established four general categories for crimes committed during the "period of heightened danger to the Republic". The first and most serious charge under the provisions of the decree was crimes committed against the state. Crimes against the state involved any perpetration of action that involved the commission of treason, violence against state authorities, the active participation in or assistance with the Nazi invasion and subsequent subjugation of the Czechoslovak Republic, all of which constituted capital offenses. Public expression of approval or

67 Douglas, 47.

68 "The Great Decree," as reproduced in Frommer, 348. 
general support for the Nazi occupation also constituted a capital offense and was punishable with death. Anyone in Czechoslovakia, who was a member of the Nationalsozialistische Deutsche Arbeiterpartei (Nazi Party) or the Sudetendeutsche Partei (SdP), faced a prison sentence of not less than five and no more than twenty years. The first chapter of the Great Decree further defined crimes against the state as any action committed abroad which detracted from or acted in opposition to the goals of the Czechoslovak state. In essence, failure to support the Czechoslovak state during the time of "heightened danger" would be severely punished. ${ }^{69}$

The second general category defined by the Great Decree was "Crimes Against Persons." This category of crimes was comprised of the traditional crimes of murder, public violence, enslavement, and manslaughter. Anyone convicted of these major crimes against individuals faced capital punishment, which was the only penalty prescribed by the law. Lesser versions of these crimes required imprisonment for ten to twenty years for each infraction of the law. Within the "Crimes Against Persons," section of the Great Decree, Benes' attempted to ensure that the legal indictments and punishments created at the end of Second Word War followed the prewar legal precedents established during the First Republic prior to the Munich Conference. The definitions for acts of murder, public violence, enslavement, and manslaughter were referenced within the penal codes of the First Republic. Another glaring example of the subjective, retributive nature of the Great Decree is the ever-present statement that in cases of extreme or egregious action committed by the accused, conviction could result in the administration of the death penalty by the courts. ${ }^{70}$

69 The Great Decree," reproduced in Frommer, 350-351.

${ }^{70}$ Ibid, 350-352 
The third general category of crimes as defined by the Great Decree was "Crimes Against Property." These crimes were the traditional crimes of robbery, willfully damaging another's property, and arson. Egregious violations of these laws resulted in the administration of capital punishment; others would be sentenced to ten to twenty years in prison. Participation in the confiscation of property that belonged to other Czechoslovak citizens, including Jews, constituted at the minimum a secondary violation of these laws resulting in punishment of twenty years to life. In the first three sections of the Great Decree, one finds the classical liberal themes of rights to life, freedom, and property. Crimes against these basic human rights were of first concern to the Benes government in the aftermath of liberation. ${ }^{71}$

The fourth general category of crime demonstrates the clear motivation behind the Great Decree. The proclamation was not only an attempt to unify and clarify the legal jurisdiction and punishments administered by the special courts and national committees; its ultimate goal was to provide an opportunity for retribution against anyone considered a collaborator. For many, the cruelest act committed during the German occupation were denunciations in which individuals informed on their neighbors, friends, and family members to the occupying forces for real, perceived, or false accusations of subversive activities. This was the most clear and concise punishment pronounced within the Great Decree:

Whoever, during the period of heightened danger to the Republic in the service or interest of the enemy, or by exploiting the situation created by the enemy occupation, denounced another for some real or invented activity, shall be sentenced to imprisonment for a term of five to ten years. If, however, the denouncer caused the loss of liberty of a Czechoslovak citizen through his denunciation, he shall be sentenced to imprisonment for a term of ten to twenty years. If the denunciation resulted, either directly or indirectly, in the loss of

${ }^{71}$ The Great Decree," reproduced in Frommer, 353 
freedom of a larger number of persons or in grievous harm to health, he shall be sentenced to imprisonment for life, and if his denunciation resulted in someone's death, he shall be punished by a sentence of death. ${ }^{72}$

The latter portion of the Great Decree sought to establish the Extraordinary People's Courts as the judicial component of the national committees. While Benes and his cabinet endeavored to assure Western observers that all care was taken to ensure the preservation of classical liberal ideals in the formation and operation of these special courts, in practice these courts failed to uphold them. National committees selected the judges appointed to the Extraordinary People's Court and Benes confirmed them. The Great Decree further established lesser Extraordinary People's Courts attached to the national committees that acted under the same premises of the Extraordinary People's Courts. Essentially, the People's Court System appeared to mimic similar court systems established in liberated France. However, within this system there was no chance of appeal, no judicial review, and ultimately no chance to overturn a verdict. However, one of the most glaring examples of the retributive nature of the Great Decree came in the form of its proscribed legal implementation of capital punishment, which required the sentence to be carried out within two hours of the pronounced verdict or, at the request of the convicted, within three hours. There was no time to apply for clemency, or for the authorities to ensure the rights of the accused; there was only time for the execution. In an even more spectacular example of the politics of vengeance, in extraordinary capital cases, the punishment could be postponed up to twenty-four hours so that the public could be gathered to watch the event:

(3) The Extraordinary People's Court may also rule that the death penalty is to be carried out in public. Such a decision should be rendered in particular in cases in which the savage nature of the crime, the degenerate character of the

72 "The Great Decree," reproduced in Frommer, 354. 
perpetrator, the number of his crimes, or his rank call for the public execution of the verdict. to ensure the public nature of the execution, in such a case the court may extend the two hour time-limit, but not beyond twenty-four hours. ${ }^{73}$

On the surface, the Great Decree appeared to be a magnanimous attempt by the Benes' government to reign in the "wild times" of the aftermath of liberation. The criminal offences described clearly target those who violated the human rights of others in Czechoslovakia. Only upon closer examination of the legal implications of the decree does its true retributive tone and motivation become apparent. The law provided little, if any, definition of evidentiary standards. Furthermore, it lacked any viable possibility of appeal making the final declaration of the given Extraordinary People's Courts was absolute, and the law required the execution of punishment, specifically capital punishment within two hours of the pronouncement of sentence. The Great Decree did little to establish the rule of law and order within liberated Czechoslovakia, but rather created state sponsored retributive justice as meted out by ad hoc courts attached to national committees staffed with vengeance-minded Czech nationalists and communists. The nightmare of retribution and vigilante as inspired by and covered by the legal guise of the Great Decree, ever-larger groups perceived to have collaborated with the Nazi occupation forces. In other words, common German ethnicity became enough evidence to convict an individual of collaboration.

\section{The Benes Legislative Agenda}

In addition to the Great Decree, Edvard Benes issued several lesser decrees designed to appropriate German property and further incite local deportations and acts of violence against minority Germans and collaborators. However, unlike the façade of ethnic blindness espoused within the Great Decree, these laws created built in ethnic

73 "The Great Decree," reproduced in Frommer, 362. 
hostilities. Due to the actions of the Nazi Germans during the occupation, and the subsequent destruction of property caused by the wars waged with and against the Nazi Third Reich, Germans were obliged to forfeit their claim to the estates and land of Czechoslovak soil that would then be redistributed to Czech peasants. The Land reform law of 1945 began:

In order to meet the call of Czech and Slovak peasants and landless persons for a new and really effective land reform and impelled above all by the desire to take Czech and Slovak soil out of the hands of the alien German and Magyar estate owners and also out of the hands of traitors to the Republic and to give it into the hands of the Czech and Slovak peasantry and landless persons, I decree on the proposal of the Government... ${ }^{74}$

However, Benes wanted the Germans to pay the bill for the chaos and

destruction that they caused. The Czechs needed significant amounts of labor in order to repair the destroyed infrastructures of industry and transportation. In a way to provide both a punishment to the Germans and supply Czechoslovak industry with the cheap-labor necessary to rebuild, the state conscripted thousands of Germans who sat in state custody.

For the purpose of removing and making good the damage cause by the war and the air raids and also of restoring the economy disrupted by the war, compulsory labor shall be introduced for persons who, in accordance with the terms of the constitutional decree of the President of the Republic of August 2, 1945, Sb. No. 33, concerning the rules governing Czechoslovak citizenship of persons of German or Magyar nationality, have lost their Czechoslovak citizenship. Compulsory labor shall also extend to persons of Czech, Slovak, or other Slav nationalities who, in the period of increased danger to the Republic, sought leave to become German or Magyar citizens without being obliged to do so by compulsion or by special circumstances. ${ }^{75}$

\footnotetext{
74 "Decree of the President of the Republic of June 21, 1945, concerning the confiscation and speedy distribution of agricultural property of Germans, Magyars and also of traitors and enemies of the Czech and Slovak people," as published in Schieder 213.

75 "Decree of the President of the Republic of September 19, 1945, concerning compulsory labor for persons who have lost Czechoslovak citizenship," September 19, 1945 as published in Schieder, 309.
} 
The Benes government that once condemned the actions of the Protectorate of Bohemia and Moravia, particularly its forced labor policies and property confiscation policies, utilized eerily similarly worded and executed laws against postwar Czechoslovakia's German minority. These laws failed to present even the façade of equality under the law for Germans and Czechs and, in essence, indicted the German population entirely as collaborators responsible for the chaos and destruction of the Second World War. No longer were these laws solely aimed at individuals responsible for the perpetration of collaborative efforts. Individuals could now be convicted based entirely upon their ethnic affiliation.

\section{The Continued Wild Times}

The Great Decree issued by President Edvard Benes sought to standardize and legalize retributive acts conducted under the administration of the national committees. The national committees approved countless acts that denied basic human rights to those who were deemed guilty of collaboration; however, they also approved acts of the same nature against civilians who were only guilty of having German ethnicity. The issuance of the Great Decree did not inherently insure the compliance of the national committees. Within the majority of the national committees, the push and desire for retribution against collaborators and minority Germans trumped any professed desire for a semblance of impartial justice. The national committees continued with the forced deportations of thousands of minority Germans to occupied Austria and Germany. Because the new Czechoslovakia lacked the stability necessary to repair many of the damaged rail lines and railroads, the forced marches of Germans continued. Where rail lines were functioning, the cattle cars, which once carried Jews, Roma, homosexuals 
and others, were now transporting nearly two thousand Germans into Austria and the occupied zones of Germany per day. ${ }^{76}$

In practice within the jurisdiction of the national committees, the Great Decree served as an inspiration for additional charges to be filed against "accused" collaborators and innocent minority Germans. Ultimately, the national committees either partially followed the decree or completely ignored it. One Czech national committee member when asked about his committee's compliance with the decree declared that the committee had never received the written decree and were operating under the rules of the Kaschau Program. In June and July of 1945, the demonstration of the retributive motivation behind the actions of some of the national committees became apparent. According to a report filed by a former official within the Czech Administrative Commission (National Committee) in Aussig, the arrests and deportations were not occurring fast enough:

The local national committees were given the task to compile a register of all persons of German nationality who were members of the Nazi Party, in preparation of their removal. Lists were compiled into the late hours of the night. In the early hours of the morning, military units made up of the Revolutionary Guard and of so-called guerillas, arrived in the affected districts. When members of the local National Committee asked them to evacuate the Germans in accordance with the compiled lists, they received very rude answers from the generally drunk "officers"- "you can put these lists up your..."

They went into action. They entered flats and every family was told to report within half an hour at the assembly point of the district. Jewelry was confiscated, and to make quite sure that nothing was hidden there, girls had even their genitals searched. Then the "transports" were loaded into tramcars and taken to Tellnitz, from where they had to walk over the Erzgebirge to Germany... ${ }^{77}$

\footnotetext{
${ }^{76}$ Douglas, 125.

77 "Report by a former official of the Czech Administrative Commission in Aussig, Reprinted from "Lodyske Listy" (London Letters, Fortnightly Review, published by Joseph Belina) vol. II, no. 14 (London, 15 July 1948), 143 directly translated from Czech in Schieder, 430-432.
} 
The criterion of ethnicity, as practiced by the Czechs in power, became enlarged by the decree, which opened the door to question the loyalty of all, especially those who were of different ethnic heritage, the Sudetendeutsche and Volksdeutsche. Charges of collaboration, murder, and slavery incited further acts of violence against the German minority as reprisal for other crimes that were committed during the Nazi occupation. National committees throughout Czechoslovakia created ethnically specific provisions in order to identify more easily the Germans who posed a threat to postwar Czechoslovak society. The Czechs repurposed many of the practices utilized by the Nazis in their administration of the Protectorate of Bohemia and Moravia. Many of the national committees required Germans to wear armbands and insignias to identify their affiliation during and after the war. The tensions reached critical mass at the end of July 1945, as evidenced once again in Aussig. An accidental explosion rocked the Schonpriesen Sugar Processing Plant, which the surrounding Czech population took to be an act of German sabotage or terrorism:

The first explosion occurred at 3.45 p.m. on 31 July 1945, shattering all windows within a radius of 3 kilometres. Nobody in the town had the slightest inkling at that moment that this was to be the signal for murder. Soldiers surrounded the bridge over the Elbe, and when Communist provocateurs arrived at 4.10 p.m., accompanied by people in Russian uniforms, the "executions" started. Germans returning from work and wearing their white armlets, became the first victims on the Benes Bridge. The soldiers had been asked by Mr. Vondra, the chairman of the local National Committee of Aussig/Elbe, to avoid any massacre; but they did not obey his order and joined in the murder. A mother wheeling her child in a pram across the bridge was killed with sticks and, together with the child, thrown over the railings into the Elbe whilst submachine guns fired at her. ${ }^{78}$

\footnotetext{
${ }^{78}$ Frommer, 83-85. "Report by a former official of the Czech Administrative Commission in Aussig," Reprinted from "Lodyske Listy," (London Letters, Fortnightly Review, published by Joseph Belina) vol. II, no. 14 (London, 15 July 1948), 143 directly translated from Czech in Schieder, 430-432.
} 
Reports of the forced marches and atrocities traveled up the chains of command to the British, American, and Soviet commanders. These accounts recorded the bloody violence, rape, pillage and plunder suffered by the Germans as the national committees began the process of deportation. Harrowing tales of individual loss and misery stunned the American forces in Austria. The American liaison officer for the expulsions in Prague, Colonel John Fye, reported that Czech leaders, in charge of the deportations, deliberately ignored the warnings issued by the Allied administration of the deportations. He also found that there were "flagrant violations of the transfer agreement" occurring, and that there were "deliberate attempts to deceive the American authorities and threats to the expellees by the commissioners of certain districts if they complained while in Czechoslovakia. When Supreme Allied Commander, Dwight D. Eisenhower, ordered the military to prohibit the entrance of any deportees into Austrian territory, the Czechs forced the Germans into a no man's land of improvised camps. For the Americans stationed on the border it was their first exposure to the cruelty of the deportation. With little food or sanitation, outbreaks of typhus and dysentery were rampant. There were several reports of American soldiers intervening on behalf of the deportees. The leadership of the British, American and even Soviet contingents began to consider alternatives to the wild deportations that were occurring in Czechoslovakia. ${ }^{79}$

\section{The Potsdam Agreement}

The Potsdam Conference was the final summit of the Grand Alliance of the Second World War. The unconditional surrender of Nazi Germany in hand, the Allied leadership continued the process of redrawing the map of Europe. Thirty years earlier the victorious Allied leadership gathered in Paris for the same reason, but its outcomes

${ }^{79}$ Douglas, 240-243. 
were ultimately disastrous for all the nations and states involved. For most of the men gathered in Potsdam from the West, the lesson of Paris 1919 was that a weak Germany was not in the interest of a lasting peace. The Americans and British came to the peace-negotiating table in search of a secure Western Europe and the creation of a United Nations. The Soviets came to the table to secure their sphere of influence in Eastern Europe. Most of the contentious points in the negotiations centered on the exact location Oder-Neisse line that marked the eastern boundary of the reconstituted Poland. ${ }^{80}$

However, a point of contention that slowly festered in the deliberations was the growing humanitarian crisis created by the deportation of Germans from Eastern Europe. Even if each government provisionally approved of partial deportations, their first concern was to ensure that war criminals could not escape prosecution through deportation to the German occupation zones. In March, April, and May 1945 alone, the Soviets authorized the deportation of more than three million Germans to occupied Germany. The British, Americans and Soviets recognized the looming humanitarian crisis would only grow worse with the approach of winter. The thousands of expellees from the east entered a decimated Germany. Allied bombing campaigns and other war related damage had destroyed the infrastructure necessary to house and feed the huge influx of population. In the summer, the lack of sanitation would prove troublesome enough, in the winter the growing death tolls would become exponential due to exposure and lack of resources, particularly food. Reports from military commanders showed the growing problems that would most certainly influence public opinion in the

\footnotetext{
${ }^{80}$ Alfred-Maurice de Zayas, Nemesis at Potsdam: The Anglo-Americans and the Expulsion of the Germans: Background, Execution, Consequences, (London: Routledge, 1977) 8-12.
} 
West. Article XIII of the initial Potsdam Agreement authorized the "orderly and humane" deportation of Sudetendeutsche and Volksdeutsche from Czechoslovakia, Poland, and the Soviet Union. When the numbers of the deportations quickly overwhelmed Allied military personnel in the occupation zones, the allies ordered an immediate halt to the deportations. ${ }^{81}$

Even with the ordered moratorium on the expulsions, the forced deportations and criminal trials continued. The Allies permitted the expulsions to resume at a decreased rate of six to eight thousand ethnic Germans per day, a number that continued to stretch the already depleted resources in occupied Germany. The administrations in Czechoslovakia, Poland, and the Soviet Union repaired the rail lines and railroads, which streamlined the deportation process. Illegally expelled Volksdeutsche from Yugoslavia, Hungary, and Romania significantly increased the number of deportees received from Czechoslovakia. Multiple checkpoints on the border reported that multiple cattle cars backed with "Germans" bound for Germany contained ethnic Germans from the Balkans. Many of these Germans from the Balkans could not speak Czech or German, so communication on these trains proved to be impossible. Though Potsdam required the trains to have enough days' rations to feed the deportees on board, too often the dead and malnourished outnumbered the healthy that disembarked the trains. The moratorium did very little to better the circumstances for those who were deported. $^{82}$

Additional reports surfaced within the American and British governments that were then leaked to the press. Where the western press once served Benes well, as it

\footnotetext{
${ }^{81}$ Bryant, Prague in Black, 127.

${ }^{82}$ De Zayas, Nemesis at Potsdam, 56.
} 
published stories that described in detail the atrocities committed at Lidice, it then became antagonistic to the Benes regime in the aftermath of the war. In August of 1945, the first questions that surrounded the humanity of the deportations appeared in the western press. The Economist evaluated the deportations as a travesty and called upon the British government to put a stop to the deportations:

The Council of Foreign Ministers must put a stop to this appalling tragedy. The wandering millions in this district are practically without food or shelter. The inhabitable parts of the large urban centres were overcrowded before their arrival, and the countryside has only limited means of housing them. The inevitable result will be that millions of them will die from hunger and exhaustion. The Germans, no doubt have deserved punishment-but not by torture of this kind. If the Poles and the Czechs wish to be rated higher in civilization than the Nazis, they will stop the expulsions at once. ${ }^{83}$

The character of the Benes' government continued to be under assault in the British Press. The following week, The Economist published another article about the disputed frontier between Czechoslovakia and Poland, describing the actions of Czechoslovakia in its claims for additional territory as sensible, choosing to restore the borders that existed prior to Munich. However, the editorial finished with another clear protest, declaring, "Unhappily, the mass expulsions of Germans and Hungarians continue. Mr. Masaryk [the Czech Foreign Minister] said, a propos of anti-Semitism, 'We shall never imitate Hitler in anything.' Unfortunately it is too late for the Czechs to make that claim." This was a correlation drawn between the packed, expulsion trains bound for Germany, and those utilized by the Nazis for the Final Solution. While this sensationalizes the relationship between the expulsions and the Holocaust, the contemporary perception drew parallels. ${ }^{84}$

\footnotetext{
83 "Mass Expulsions in Eastern Europe," The Economist, (September 15, 1945) 369.

84 "A Disputed Frontier," The Economist, September 22, 1945, 411.
} 
In October of 1945, the New York Times published an article that stated Britain had requested the cooperation of the rest of the Big Four, including France, the United States and the Soviet Union, in pressuring Poland and Czechoslovakia to cease in the prosecution of expulsion orders. The article referred to a wire dispatched from London, discussing a hearing held in the House of Commons in which members of Parliament pleaded with the British Under-Secretary of Foreign Affairs, Herbert MacNeil, to apply additional pressure to the restored eastern states to halt the deportations.

Referring to Mr. Stokes' Plea that a great many people involved were innocent of wrong-doing Mr. MacNeil said that he could not accept this. "They are, I'm afraid, Germans and either through their rulers or themselves have visited on the Poles, Czechs and Russians, Christians as well as Jews, monstrous cruelties," he said. ${ }^{85}$

This declaration of Under-Secretary MacNeil provided a significant window into the conundrum faced by the administrations of the Allied states. On the one hand, there was a justifiable need to punish the people responsible for humanity's bloodiest conflict and greatest crimes. However, for many of these leaders, the ghosts of the Versailles Peace Conference of 1919 haunted their every action. At Versailles, the British and French lobbied for significant penalties and reparations against the Germans who were forced to claim full responsibility for the First World War, a treaty provision that enraged many Germans during the Weimer era. One of the most useful propaganda points utilized by Hitler's National Socialist Party was its continuous agitation for the return of Germany to its rightful place as the continental power it had been under the direction of Chancellor Otto von Bismarck. For many historians, the ascension of Hitler's Nazi party occurred due to the economic and political conditions created by the Versailles Treaty.

\footnotetext{
${ }^{85}$ Wireless to The New York Times. "Britain Asks the Big Four to Warn Poland," The New York Times, October 11, 1945. ProQuest Historical Newspapers.
} 
The Weimar Republic never recovered from the crises of the interwar period and was forever tainted by its submission at Versailles. ${ }^{86}$

The leadership in Washington, London, and Paris determined that under no circumstances would the mistakes of Versailles be replicated at Potsdam and throughout the reconstruction period in Europe. The Americans and British determined that hunting the individuals responsible for the war crimes perpetrated by the Nazi Third Reich was the top priority. They would then prosecute them, based on legal charges presented before an international military tribunal based in Nuremburg after the war, which would provide the justice desired by their respective populations. This approach would then leave the general population of Germany susceptible to liberal democratic influence, and would not drive Germans into the communist fold. For the Germans of Eastern Europe, there was hope; however, it was only a glimmer as the "orderly and humane" deportations continued. ${ }^{87}$

As late as 1947, the deportations continued from Eastern Europe. The flow of expellees from Czechoslovakia slowed because nearly two million had already been deported between May of 1945 and May of 1946 . Less than four months into the deportations, the Soviets declared the eastern occupation zone of Germany to be at capacity and forced all further expellees to be sent to the British and American zones. The British and Americans faced insurmountable shortages in all major provisions and space in which to settle the millions of expellees. In November of 1945, New York

\footnotetext{
${ }^{86}$ For an excellent study on the effects of the Treaty of Versailles on Europe, refer to Macmillan, Margaret. Paris 1919: Six Months that Changed the World. (New York: Random House, 2003).

87 "German Politics," The Economist, October 13, 1945, 514-516.
} 
Times reporter Sydney Gruson reported that the death of thousands of "ill-clothed, ill-fed refugees from these regions [Poland and Czechoslovakia]" ${ }^{88}$

The organized expulsions from Czechoslovakia failed to settle the tensions between Czechs and Germans, as was visible along the Czech border with Austria and the occupied zones of Germany. The large numbers of unsettled, starving, angry refugees became more and more restless. In a report to The New York Times, John McCormac reported that Sudeten Germans were forming armed gangs and launching forays back across the Czech border, terrorizing the Czechs of the Sudetenland. These raids continued until the Czechs ordered military border patrols to stop them. However, these raids provided the Czechoslovak government with fodder to continue the deportations in the interest of peace. ${ }^{89}$

International pressures to stop the deportations increased continually and when these pressures reached critical mass, the expulsions ended. However, the time that was necessary to build up the international pressures was just enough for the Benes government to remove the bulk of the minority German population, leaving an insignificant few thousand behind. Czechoslovakia, once the mythological model of a democratic state that provided minorities with equal rights, now became a homogenous ethnic state in its Czech and Slovak parts. From this point on, there was no paradigm of Czech-German relations, no tenuous coexistence, only the memory of what each group inflicted upon the other.

${ }^{88}$ Sydney Gruson. "Deportations of Germans Add to Europe's Troubles, Allies Having Taken Care of Millions of 'Displaced Persons,' try to stop them," The New York Times, (November 18, 1945.) ProQuest Historical Newspapers.

${ }^{89}$ McCormac, John. "Expelled Germans Stir Czech Border: Settlers Receive Threatening Postcards-Forays Across the Frontier are Reported," The New York Times, April 14, 1947. ProQuest Historical Newspapers. 


\section{Conclusion}

\section{The Expulsions in Modern Memory}

The expulsion of the Sudetendeutsche and Volksdeutsche from the Czechoslovak Republic continued to haunt the country after the Second World War. When the Communists, under Klement Gottwald, took control of the government of Czechoslovakia in 1948, they sought to silence the discussion and suppressed the collective memory of the deportations. In Western Germany, research and discussions concerning the deportations continued as historians and political activists accumulated numerous first hand accounts and other primary sources about the expulsions. By the 1960s, the community of German expellees became an important political force within Western German politics. It was not until the 1989 fall of the communist regime in Czechoslovakia that discourse about the expulsions restarted in earnest. The release of thousands of documents once held under tight security by the communist regime in Czechoslovakia led to new calls for reexamination of one of history's largest and most tragic population transfers. These reexaminations, and the documents released, reawakened the world to the tragedies that befell the German minorities of Eastern Europe as the liberated governments stripped them of their citizenship, their identities, their property, and for millions, their lives.

In the aftermath of the Second World War, Western Europe began to rebuild itself rapidly. By the fifties and sixties, Western Europe experienced renewed prosperity, the main motor of which was the economic miracle in West Germany. In repentance for the atrocities and terror unleashed by the Nazi Third Reich, the West Germans admitted to and issued apologies for the actions of the Nazi Third Reich. In West Germany, the population of expellees became politically active and formed 
refugee organizations devoted to the political interests of the German expellees. They demanded reparations and compensation for the victims of expulsions. While the Eastern Bloc nations never met their demands, these groups continued to work instrumentally within the West German government shaping policy toward their former homelands.

Throughout the process of remembering these expulsions, there continued to exist a constant tension between the narratives of genocidal perpetrators and victim of ethnic cleansing. Historian Robert G. Moeller in his work, War Stories: The Search for a Usable Past in the Federal Republic of Germany, carefully examined the impact of this struggle. He dismissed the traditional narrative that accused the Germans of "forgetting" the crimes of the Nazi past. Instead, through his collection of primary sources including first-hand accounts, he discovered that for the majority of Germans the stigma of perpetrator was far less preferable to the narrative of victimhood. They practiced "selective remembering" according to Moeller. In other words, they chose to remember events that victimized the Germans, events that they contemporarily compared directly to the sufferings of Jews during the Holocaust. This tension still fuels debate in modern Germany. ${ }^{90}$

The German reunification of 1989 brought forward a new chorus of apologies and assistance from the German government for the actions of the Third Reich, as well as demands for Eastern governments to apologize for their actions during the expulsions. The expellee political organizations found within Eastern Germany other expellees who identified with their cause. While negotiations between Eastern national

${ }^{90}$ Robert Moeller, War Stories: The Search for a Usable Past in the Federal Republic of Germany, (Berkley: University of California Press, 2003) 330-332. 
leaders and the German leaderships began immediately following the communist collapse, the Europeans spent the lion's share of the 1990s debating responsibility versus justification for the expulsions throughout Eastern Europe. The Germans for their part, provided apologies and additional economic assistance for post-communist states that helped pave the way for a more united European continent, and made further reconciliation possible. ${ }^{91}$

In 1997, the German Chancellor Helmut Kohl and Czech President Václav Havel worked tirelessly to create a document in which each nation admitted to and apologized for his nation's actions toward the other. While the document was signed and ratified, it did very little to soothe the tensions that still existed between Czechs, who felt victimized at Munich in 1938 and during the Nazi occupation, and Germans, who felt victimized in the aftermath of the war during the mass expulsions from the East.

Though international communication and cooperation seemed in the best interest for both nations, tensions created by a contested past only escalated as the Czech Republic began the process of gaining access to, and membership in, the European Union at the turn of the twenty first century. ${ }^{92}$

Prior to 1989, the European Union consisted entirely of the nations of Western Europe in an economic and political community. The fall of the Soviet Union created a security and economic vacuum in Eastern Europe that led many of its nations to seek admittance into the North Atlantic Treaty Organization and the European Union. The political separation of the Czech Republic and Slovakia in January 1993 was

\footnotetext{
${ }^{91}$ William I. Hitchcock, The Struggle for Europe: The Turbulent History of a Divided Continent 1945-Present, (New York: Anchor Books, 2003) 253-257.

92 Craig R. Whitney, "Czechs and Germans Try to Heal Hatreds of the Nazi Era," The New York Times (January 22, 1997) www.nytimes.com (Accessed: September 21, 2012) 1-2.
} 
accompanied by increasing popular desire, especially among Czechs, to enter into the European Union. However, many refugee and expellee activist groups in Germany demanded that Czech admittance to the European Union be tied to a renunciation and repeal of the postwar laws of retribution. However, the British Lord Kingsland, British Minister for Legal Affairs, declared to the British Government that the Benes Decrees placed no impediment in the path of Czech membership in the European Union. ${ }^{93}$ In a report from the Centre for European Reform in 2002, the European Commission declared that the laws were not an obstacle to the admission of the Czech Republic to the European Union:

The European Commission holds that the Benes decrees are not an obstacle to Czech or Slovak accession, although the European Parliament's views are more ambivalent. There is no evident legal basis in the EU's treaties that would allow a historical injustice to disqualify a country from membership, but any continuing application of the decrees in Czech law would be incompatible with the antidiscrimination provisions in the treaties. The accession conditions involve criteria on democracy, human rights, and respect for and protection of minorities, but they relate to current practice rather than past wrongs. The EU's focus is on encourage [sic] the reconciliation in central Europe. ${ }^{94}$

Despite the findings of the European Commission, the Benes Decrees still elicited continued problems for the accession of the Czech Republic into the European Union. From 2000 to 2007, political opinions among the European Union members polarized along support for and against the Czech Republic's position that their laws passed from 1945-1948 did not fall under the purview of the Lisbon Treaty. According to the same Centre for European Reform report, right wing politicians in Austria and Germany demanded that the accession be blocked in the interest of justice for the

\footnotetext{
${ }^{93}$ Lord Kingsland, QC. "Observations on the Benes Decrees and the Accession of the Czech Republic to the European Union," Legal Opinion published by Her Majesty's Government (October 2, 2002), (Accessed on May 1, 2012) 14-15.

${ }^{94}$ Heather Grabble, "Briefing Note: The Benes Decrees implications for EU Enlargement," Centre for European Reform: New Ideas for a New Europe, (June 2002) 1.
} 
Sudeten Germans. Then Czech President, Vaclav Klaus, described the Sudeten Germans as "Hitler's Fifth Column" and suggested that they received the punishment they deserved. The Czechs and Slovaks pointed to the finding of the European Commission as exonerative of their government. Nationalist German and Austrian Politicians argued that if the expulsions were not a legal roadblock, they were at least an ethical one. When the European Union finally announced the approval of the Czech Republic as a member of the European Union, many believed the issue would die down. ${ }^{95}$

In 2004 and 2005, prior to the accession of the Czech Republic, separate opinion polls published in British publications declared that a majority of Czechs supported the maintenance of the decrees, while only a small fraction of the population argued for the immediate repeal. In a poll conducted in 2011, four years after the Czech Republic's admittance into the European Union, CzechPosition.com published a political poll in which $49 \%$ of Czechs favored the preservation of the Benes Decrees a decline of $16 \%$ from a 2009 poll in which $65 \%$ of Czechs favored the maintenance of the laws. However, within both polls the percentage of the population that favored the repeal of the laws in their entirety remained a minority. An even more revealing portion of the poll asked respondents about their attitude toward the necessity and legality of the forced deportations. That portion of the poll indicated that $42 \%$ of Czechs considered the expulsion policies fair. $25 \%$ said that they were unfair but that actions of the past had a statute of limitations. Seven percent declared that an apology was due, and four

${ }^{95}$ Grabble, 2. and Steve Peers, "The Benes Decrees and the EU Charter of Fundamental Rights," StateWatch.org, University of Essex, (October 12, 2009). http://www.statewatch.org/ news/ 2009/oct/lisbon-benes-decree.pdf. (Accessed: February 1, 2012) 5-10. 
percent declared that the policies were unfair and that compensation should be paid and property restituted to its rightful owners. ${ }^{96}$

The long shadow cast by the forced deportations of minority Germans from the Czechoslovak republic still haunts the modern Czech government. Despite the passage of over six decades, the Czechs still face tough questions from the expellee communities abroad. In Germany, the group Zentrum gegen Vertreibungen (ZGV— Center against Expulsions) created museums and archives devoted to the memory of the expellees. These institutions rekindled the debate over the expulsions for a new generation of Czechs and Germans. While the center's mission statement declares that it "was founded in the spirit of reconciliation with all neighboring peoples... [and] with all victims of expulsion or genocide," its efforts have been met with skepticism from Polish and Czech leaders. Another group, the Deutsche Weltallianz (DWA—German World Alliance) exhaustively formed to search for additional evidence regarding the expulsions. In 2010, the DWA broke a story about the discovery of a mass grave of Germans outside the Czech village of Dobronin. The thirteen Germans were executed at the end of the Second World War. Once again, the memory of the expulsions was renewed in both German and Czech National consciences. ${ }^{97}$

Czechs resolved the issue of Czech-German relations in Bohemia and Moravia and eliminated the German presence through deportation. Now they face questions as

\footnotetext{
${ }^{96}$ Tom Jones, "Half of Czechs Favor preserving Benes Decrees-Growing number of Czechs favor abolishment of decrees that led to post-war expulsion of Sudeten Germans from Czechoslovakia" CzechPosition.com, January 1, 2012. www.ceskapozice.cn/en/news/ society/half-Czechs-favor-preserving-benes-decrees. (Accessed: February 1, 2012.) 1-2. 97 "Our Foundation Tasks and Objectives," Zentrum gegen Vertreibungen, http://www.z-gv.de/english/aktuelles/?id=35, (Accessed: February 25, 2013), and "Massacre of Bergersorf: Remains found at site of alleged 1945 murder of German Civilians," Deutsche Weltallianz, (August 16, 2010), http://germanworldalliance.org/news.html, 10. (Accessed: February 10, 2013.)
} 
to the statutes of limitations on crimes against humanity, and what to do with regimes and populations that continue to support laws that led to the expulsion and deaths of millions during their transport to their "native" country of origin. In modern Czech society, the heinous crimes perpetrated by the Nazis against the populations of Bohemia and Moravia warranted the harsh treatment of the Germans under the Benes Decrees and Potsdam Agreements. Despite its clearly ethnic applications, the legislation signed into law by Edvard Benes in 1945 continues to hold the status of legal precedent in the Czech Republic. ${ }^{98}$

\section{The Specter of the Cattle Cars}

After 1942, millions of people boarded trains with what few possessions they were permitted to take, separated from their family and friends, and sent to destinations they only vaguely knew or understood. Under the Nazi Third Reich, these rail lines led to concentration camps, forced labor, and ultimately death for the Jews, Roma, and others forced onto them. The cramped, unsanitary conditions and lack of ventilation killed many in transit. For those who survived, death waited through overwork, malnourishment, exposure, and the gas chambers. In the aftermath of the Second World Ward, trains once again became a tool for redrawing the political, social, cultural, and ethnic maps of Europe. In the interest of a lasting peace, the Allied Powers recognized the necessity to move troublesome minority groups to their ethnic heartlands. This operation applied particularly to the millions of Germans in Czechoslovakia, Poland, and the Soviet Union.

In the case of Czechoslovakia, these deportations marked a significant change in the history of ethnic relations in Bohemia and Moravia. Historically, these crown lands

${ }^{98}$ Jones, 2. 
had been part of the Habsburg Empire for centuries. From that time, a complex coexistence characterized the relationship between the resident Czechs and Germans. The Habsburg Empire's nationalist liberals attempted to centralize its power in Bohemia through state sponsored schools that only taught in German, the requirement that all official business conducted in the German language, and the political dominance of Germans. Though these actions were part of a far more complex overhaul of the administration of the Habsburg Empire, for Czech nationalists it was an attempt to minimize Czech culture and language in favor of the German culture and language. The Czechs responded with private Czech schools, local business conducted in Czech, and their continued support for the Austrian Emperor in Vienna over the Germans in power in the legislature and at the local level. However, the relations between Czechs and Germans cannot be narrowly defined in the terms of conflict or competition, but also in cooperation, coexistence, and the intermarriage and transience of identity that existed between the two groups. In essence, there were no solid defining lines between the two groups so that participation was not in and of itself exclusionary.

The First World War ushered in a change of official political power in the region as the then Austro-Hungarian Empire was dismantled by the victorious Allied powers at the Paris Peace Conference. Under the direction of Tomas Masaryk and his lieutenant, Edvard Benes, the Czech leadership abroad labored the allied leadership in London, Washington, Paris and Rome for the creation of a separate Czech State. In order to lend additional credibility to this new nation-state, Masaryk, Benes, and other Czech nationalists promoted the nineteenth century idea of a mythical medieval Czech state that was once the beacon of democracy in Eastern Europe before it fell into the hands 
of the barbarian Germans. Masaryk argued that a Czech state would create the buffer necessary to contain Germany, and separate the rest of Europe from the Red communist menace brewing in the Soviet Union.

The Allies ratified the creation of a multinational state known as Czechoslovakia. Within the territory appropriated for this new state, three and a half million Germans found themselves transplanted under a new national flag. Though Masaryk remained a declared republican and proponent of democracy, his subordinates, specifically Benes, pressured the president for additional legal measures to restrict the participation of Germans in the national government while granting them real participation in local Sudetenland governments. Even with this tightening of restrictions upon the Germans in Czechoslovak society, individuals still maintained their transience of identity impeded only moderately by their physical appearance. When Benes succeeded Masaryk, the continued pressure on the Germans limited but did not eliminate those who could act as members of each group.

The Munich Conference of 1938 and the outbreak of the Second World War in 1939 ushered in another chapter in Czech-German relations. The Nazi Third Reich under Adolf Hitler sought to absorb all of the territories that contained substantial numbers of Germans and ultimately the expansion of Germany to the territories to the East. Within the Nazi plans, the newly created Protectorate of Bohemia and Moravia (from parts of Czechoslovakia) would be populated with Germans while the majority of the Czech population would be enslaved or removed, ultimately changing the ethnoracial makeup of the region. To oversee the Germanization of the Protectorate, Hitler appointed Konstantin Von Neurath as the Reichsprotektor. Neurath recognized the 
impracticality of the forced migration of all or the majority of the Czech population, which would leave the Protectorate desolate. Further complicating his assignment was the immense mixing between racial groups that existed in the region. The region's industries, specifically the Skoda Works, were important suppliers of war material for the entire Reich. Instead, Neurath convinced Berlin that the mixing of German and Czech blood in the region made most of the population suitable for Germanization. Slowly Neurath proceeded with the approved plans for the Germanization of the population, but he feared an uprising of Czechs and permitted them to express national identity, which the Czech president-in-exile, Edvard Benes hoped to transform into acts of solidarity and resistance.

As the intensity of these acts grew with the continuation of the war, the Nazi leadership sought a change in the administration of the Protectorate, and for that purpose, Hitler appointed the security chief, Reinhard Heydrich, as the Reichsprotektor. Heydrich brought with him an incredible military discipline and personal belief in the racial ideology of the Reich. He immediately cracked down on the resistance movements, and increased the deportations of Jews and Gypsies. He further created concrete racial delineations between the ethic Germans and ethnic Czechs. This process polarized society in the Protectorate between the two groups, while simultaneously maintaining a tenuous peace. The pacification of Czech society enraged Czech President-in-Exile Edvard Benes who immediately pressured the resistance groups for a high profile action that would get the attention of the Allied Powers. The assassination of Reinhard Heydrich as planned by Benes led to the destruction of the Czech village of Lidice in reprisal, as well as the immediate and 
devastating crackdown on nationalist and communist resistance groups in the region. While internationally this helped to solidify Benes' position for the reestablishment of the Czechoslovak state, Czechoslovak resistance was rendered virtually nonexistent for the remainder of the war and only manifested itself in small-organized work slowdowns and absenteeism.

Abroad Benes continued to lobby the Allied leadership for its approval of his postwar policies that would remake the ethnic map of Czechoslovakia by forcing the deportation of the region's Sudetendeutsche and Volksdeutsche in the interest of a lasting peace, while pointing to the two world wars caused by the Germans as justification for his policies. The massacre at Lidice solidified the provisional support of the Allies, and enabled Benes to begin planning the deportations. Through radio addresses and speeches, Benes called upon the population of Czechoslovakia to welcome and assist the Red Army, ensure the capture of all collaborators, and begin the deportations of those determined to have supported the Nazi Occupation of the Czechoslovak state. On May 5, 1945, the historical relationship between Czechs and Germans was fundamentally transformed. The remnants of the Czech resistance rose up and crushed the German troops charged with holding the city. The Czechs then went about the capture of all suspected war criminals, which boiled down to collaborators of all ethnicities, and ethnic groups thought to have collaborated. In other words, being German made a person guilty of collaboration. During these "wild times" of deportations, the Czech national committees and the population in general incarcerated thousands of Germans while simultaneously raping, pillaging, and plundering with the Red Army soldiers that had liberated them. 
The Czech national committees, under the direction of the Kaschau Program and the Benes' Decrees, forced other Germans to depart their dwellings with little or no personal belongings and marched or transported them by train to the German or Austrian borders. Those who were not deported initially faced repeated acts of brutality from Czechs and Red Army personnel, and then after having their personal property stripped from them, they too were deported to Germany or Austria. Czech President Edvard Benes only paid lip service to Allied declarations that had demanded the "orderly and humane" transfer of populations in the Potsdam Agreement. The Czech national committees carried out the execution of convicted prisoners within two hours of the pronouncement of sentence. The forced marches to the borders and the conditions on the trains left thousands dead from exposure, malnutrition, and disease. Within the Czech laws, particularly the Great Decree and the Kaschau Program, there was little differentiation made between collaborators and Germans. The creation of temporary governance in the liberated areas did very little to curtail the actions that first occurred during the wild times.

The Czech national committees also adopted Nazi-style practices against the Germans themselves. The Czechs separated, concentrated, and deported the Germans who were not of some use to the state. The Czechs imprisoned many Germans in the same concentration camps that once housed Jews, Roma, and others. Some Germans were utilized in forced labor, made to wear identifying armbands, and faced additional acts of violence and retribution. Once again, not all, or even necessarily a majority of those individuals who suffered these fates were in fact active collaborators or even individuals who approved of the Nazi occupation forces. The 
outside force of the German Third Reich acted upon, changed, and transformed the relationship between Germans and Czechs in Bohemia and Moravia. No longer was there a common ground that had permitted both groups to continue to coexist. By the end of the deportations, the Germans who remained in Czechoslovakia were a sparse few when compared with the millions who once called the former Austrian crown lands home.

The explanation of Czech-German relations as a competition between the two groups has no merit because these relations were made far more complex through coexistence, cooperation, intermarriage, and the transience of identity. Neither of the groups had sought the destruction or removal of the other group and only acted to elevate one group over the other. The creation of the Nazi Third Reich, with its racial ideology and dogma combined with its desired geographical expansion to include regions beyond Germany's 1919 borders, introduced an additional force in the relationship. The systematic Nazi operations to purify its territories through the deportation, concentration and extermination of those deemed racially unfit, especially the Jews and Roma, created the psychological breakthrough necessary to make the removal of a troublesome minority a logical possibility. The Nazi Third Reich also provided models for carrying out mass population transfers. Without the overarching protection of the Third Reich and the Wehrmacht, the Germans left behind were at the mercy of the vengeful Red Army and liberation governments.

The actions of the Czechoslovak administration, and those of other central and east European states, in the aftermath of the Second World War, created one of the largest humanitarian crises in world history. The Czech government kept its promise to 
prosecute and punish individuals who collaborated with the Nazi occupation forces, but it also punished the Germans who were citizens of Czechoslovakia prior to the war, through ethnically motivated laws designed to cleanse the state of minority populations. In other words, without necessarily denouncing all Volksdeutsche as collaborators, the Benes government made it the logical conclusion when the national committees enforced the laws.

However, the impact of these deportations extended far beyond the 1948 Communist takeover in Czechoslovakia. Following the 1989 collapse of the Communist regime, many Germans opposed the expansion of the European Union to include the Czech Republic until the Czechs renounced and repealed the Benes decrees. Despite multiple legal opinions from throughout the European Union that declared the decrees had no effect on the Czech Republic's participation in the Union, many Germans believed that it was a direct affront to Germany that they be admitted with the decrees still intact. Even more infuriating for Germans were Czech opinion polls that demonstrated continued popular support for the Benes' decrees. Not only in the German view were the Czechs unapologetic, they still espoused support for the policies of ethnic cleansing established by the Benes government. The accession of the Czech Republic to the European Union did very little to quell Czech public sentiment in favor of the Benes decrees, as currently a significantly large portion of the Czech public still approves of the laws, while only a minority favors their repeal.

For the many Czechs and Germans, the Benes Decrees and their consequences remain ever-present. At the end of history's deadliest war, the injustices continued. While the Benes Regime punished many true collaborators, many more individuals that 
were innocent, faced deportation and their own mortality aboard the very trains that once transported thousands of Jews and Roma to extermination camps in the East. Though this study in no way seeks to equate the Holocaust with the postwar expulsions, it does seek to change our understanding of the dramatic change in the relationship between Czechs and Germans in the course of less than a decade. In truth, the Nazi occupation authorities and the Benes administration altered forever the historical relationship between Czechs and Germans, and redefined it as an existential conflict that still plagues both Czech and German societies today. 


\section{Bibliography}

\section{Primary Sources}

"A Disputed Frontier," The Economist, September 22, 1945, 411.

Benes, E. "The Organization of Postwar Europe," Foreign Affairs Vol. 20 No. 2. January 1942. 287.

Benes, Dr. Edvard. Sest let exilu a druhe svetove valky: Reci, projevy a dokumenty $z$ r. 1938-1945. Prague: Orbis, 1946. 39-41. reproduced on www.antikvariatking.cz/pdf/S\%20-\%2024.pdfSimilar, translated via Google translate. Accessed: June 1, 2012.

Fierlinger, Zdnek. "We Are Rectifying White Mountain," Prague: Jednotny svaz cskych zemedelco, 1945. 3-7.

"German Politics," The Economist, October 13, 1945, 514-516.

Gebbels Joseph. "The True Meaning of the War" as reproduced in Griffin, Robert, Ed. Fascism: Oxford Reader. New York: Oxford University Press, 1995.

Grabble, Heather. "Briefing Note: the Benes Decrees' Implications for E.U. Enlargement," Centre for European Reform: New Ideas for a New Europe. June, 2002. 1-2.

Gruson, Sydney. "Deportations of Germans Add to Europe's Troubles, Allies Having Taken Care of Millions of 'Displaced Persons,' try to stop them," The New York Times, November 18, 1945. ProQuest Historical Newspapers.

Jones, Tom. "Half of Czechs Favor preserving Benes Decrees-Growing Number of Czechs favor abolishment of decrees that led to post-war expulsions of Sudeten Germans from Czechoslovakia." CzechPosition.com January 1, 2012. www.ceskapozice.cn/en/news/ society/half-Czechs-favor-preserving-benesdecrees. Accessed February 1, 2012.

Kingsland, Lord Q.C. "Observations on the Benes Decrees and Accession of the Czech Republic to the European Union." Legal Opinion published by Her Majesty's Government, October 2, 2002. Accessed on May 1, 2012.

Labour Party, National Executive Committee. International Postwar Settlement, January 1945.

"Mass Expulsions in Eastern Europe," The Economist, September 15, 1945, 369. 
McCormac, John. "Expelled Germans Stir Czech Border: Settlers Receive Threatening Postcard-Forays Across the Frontier are Reported," New York Times, April 14, 1947. ProQuest Historical Newspapers.

Peers, Steve. "The Benes Decrees and the EU Charter of Fundamental Rights," StateWatch.org. University of Essex, October 12, 2009. 5-10. http://www.statewatch.org/news/ 2009/oct/lisbon-benes-decree.pdf.

Whitney, Craig R. "Czechs and Germans Try to Heal Hatreds of the Nazi Era," New York Times. January 22, 1997. www.nytimes.com. Accessed: September 21, 2012.

Wireless to The New York Times. "Britain Asks the Big Four to Warn Poland," The New York Times, October 11, 1945. ProQuest Historical Newspapers.

\section{Primary Source Collections and Archives}

Dolezal, Jivi, and Jan Kren, eds. Czechoslovakia's Fight: Documents on the Resistance Movement of the Czechoslovak People, 1938-1945. Prague: Czechoslovak Academy of Sciences, 1964.

"From R. Heydrich's monthly report to the Reichskanlei." May 18, 1942 "Part of the Short-hand Record of a Speech by the Reichsprotektor, R. Heydrich in Prague." October 2, 1941.

"Report by Dr. Geshke on the Destruction of Lidice, June 24, 1942." June 24, 1942.

Lesson from History: Documents concerning Nazi Policies for Germanization and Extermination in Czechoslovakia. Prague: Orbis, 1960.

"Memorandum on the Question of the Future Settlement of the BohemianMoravian Area." August 31, 1940.

"Proposals for the Preparation of Germanisation (National Mutation) in the Protectorate of Bohemia and Moravia." November 30, 1940

"Report to the Fuhrer for the period from May to September 1, 1942." September $1,1942$.

“Sudeten German Party’s Action Programme of 1938," Czechoslovakia, 1938

Schieder, Theodor ed. Documents on the Expulsion of the German Population from Czechoslovakia. Vol. 4. Bonn: Federal Ministry for Expellees, Refugees, and War Victims, 1960. 
"Decree of the President of the Republic of June 21, 1945, concerning the confiscation and speedy distribution of agricultural property of Germans, Magyars and also of traitors and enemies of the Czech and Slovak people." June 21, 1945.

"Decree of the President of the Republic of September 19, 1945, concerning compulsory labor for persons who have lost Czechoslovak citizenship." September 19, 1945.

"Expulsion Notice from Landskron"

“Okresni spravni komice ve Frydlante v. C." June 15, 1945.

"Report by a former official of the Czech Administrative Commission in Aussig, Reprinted from "Lodyske Listy." London Letters, Fortnightly Review, published by Joseph Belina) Vol. II, no. 14. London, July 15, 1948.

"Report of the Experiences of Dr. Korkisch, University Lecturer of Prague." Original dated March 2, 1947.

"Report of the Experiences of Elisabeth Peshke, farmer's wife, of seifersdorf, district Jagerndorf." Original dated April 17, 1947.

"The Kaschau Programme-Programme of the new Czechoslovak Government of the national Front of Czechs and Slovaks, accepted at the first cabinet council held on April 5, 1945." April 5, 1945.

\section{Secondary Sources}

Andelman, David A. A Shattered Peace: Versailles 1919 and the Price We Pay Today. New Jersey: John Wiley \& Sons Inc., 2008.

Brown, MacAlister. "The Diplomacy of Bitterness: Genesis of the Potsdam Decision to Expel Germans from Czechoslovakia," The Western Political Quarterly, Vol. 11 No. 3 (September, 1958) 607-626.

Bryant, Chad. "Either Czech or German: Fixing Nationality in Bohemia and Moravia, 1939-1946," Slavic Review Vol. 61 No. 4 (Winter 2002) 683-706.

Bryant, Chad. Prague in Black: Nazi Rule and Czech Nationalism. Cambridge, Harvard University Press, 2007.

Curp, T. David. A Clean Sweep? The Politics of Ethnic Cleansing in Western Poland, 1945-1960. Rochester: University of Rochester Press, 2006.

Douglas, R. M. Orderly and Humane: The Expulsion of the Germans after the Second World War. New Haven: Yale University Press, 2012. 
Frommer, Benjamin. National Cleansing: Retribution against Nazi Collaborators in Postwar Czechoslovakia. Cambridge: Cambridge University Press, 2005.

Hitchcock, William I. The Struggle for Europe: The Turbulent History of a Divided Continent 1945-Present. New York: Anchor Books, 2003.

Homze, Edward L. Foreign Labor in Nazi Germany. Princeton: Princeton University Press, 1967.

Kelly, David D. The Czech Fascist Movement, 1922-1942. Boulder, Co: Eastern European Monographs, 1995.

King, Jeremy. Budweisers into Czechs and Germans: A Local History of Bohemian Politics, 1848-1948. Princeton, NJ: Princeton University Press, 2002.

Lukes, Igor. Czechoslovakia between Stalin and Hitler: The Diplomacy of Edvard Benes in the 1930s. Oxford: Oxford University Press, 1996.

MacDonogh, Giles. After the Reich: The Brutal History of the Allied Occupation. New York: Basic Books, 2007.

MacMillan, Margaret. Paris 1919: Six Months that Changed the World. New York: Random House, 2003.

"Massacre of Bergersorf: Remains found at site of alleged 1945 murder of German Civilians," Deutsche Weltallianz. August 16, 2010. http://germanworldalliance. org/news.html. 10. Accessed: February 10, 2013.

Mastny, Vojtech. The Czechs Under Nazi Rule. New York: Columbia University Press, 1971.

Meyer, G.J. A World Undone: The Story of the Great War 1914-1918. New York: Oxford University Press, 2011.

Moeller, Robert. War Stories: The Search for a Usable Past in the Federal Republic of Germany. Berkley: University of California Press, 2003.

Naimark, Norman. Fires of Hatred: Ethnic Cleansing in Twentieth-Century Europe. Cambridge: Harvard University Press, 2002.

Orzoff, Andrea. Battle for the Castle: The Myth of Czechoslovakia in Europe 19141948. New York: Oxford University Press, 2011.

"Our Foundation Tasks and Objectives," Zentrum gegen Vertreibungen. http://www.z-gv.de/english/aktuelles/?id=35. Accessed: February 25, 2013 
Rossino, Alexander B. Hitler Strikes Poland: Blitzkrieg, Ideology and Attrocity. Lawrence: University of Kansas Press, 2003.

Snyder, Timothy. Bloodlands: Europe Between Hitler and Stalin. New York: Basic Books, 2010.

Sutton, Guy. "The Weekend Crisis" of May 1938: Analyzing an Unsolved Mystery in Czechoslovakia-Nazi Germany Relations. New York: I Universe, Inc, 2005.

Terry, Sarah M. Poland's Place in Europe: General Sikorski and the Origin of the Oder=Neisse Line, 1939-1943 . Princeton: Princeton University Press, 1983

Wighton, Charles. Heydrich: Hitler's Most Evil Henchman. Philadelphia, 1962.

de Zayas, Alfred-Maurice. A Terrible Revenge: The Ethnic Cleansing of the East European Germans, 1944-1950. New York: St. Martin's Press, 1993.

de Zayas, Alfred-Maurice. Nemesis at Potsdam: The Anglo-Americans and the Expulsion of the Germans: Background, Execution, Consequences. London: Routledge, 1977. 